\title{
Thirty-Year Solid Waste Generation Forecast by Treatability Group
}

by

c. Thomas

Westinghouse Savannah River Company

Savannah River Site

Aiken, South Carolina 29808

DOE Contract No. DE-AC09-89SR18035

This paper was prepared in connection with work done under the above contract number with the U.S. Department of Energy. By acceptance of this paper, the publisher and/or recipient acknowledges the U.S. Government's right to retain a nonexclusive, royalty-free license in and to any copyright covering this paper, along with the right to reproduce and to authorize others to reproduce all or part of the copyrighted paper.

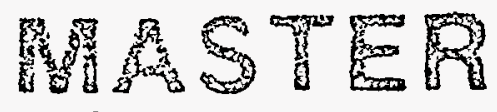




\section{Thirty-Year Solid Waste Generation Forecast by Treatability Group ${ }^{(U)}$}




\section{DISCLAIMER}

This report was prepared as an account of work sponsored by an agency of the United States Government. Neither the United States Government nor any agency thereof, nor any of their employees, makes any warranty, express or implied, or assumes any legal liability or responsibility for the accuracy, completeness, or usefulness of any information, apparatus, product, or process disclosed, or represents that its use would not infringe privately owned rights. Reference herein to any specific commercial product, process, or service by trade name, trademark, manufacturer, or otherwise does not necessarily constitute or imply its endorsement, recommendation, or favoring by the United States Government or any agency thereof. The views and opinions of authors expressed herein do not necessarily state or reflect those of the United States Government or any agency thereof.

This report has been reproduced directly from the best available copy.

Available to DOE and DOE contractors from the Office of Scientific and Technical Information, P.O. Box 62, Oak Ridge, TN 37831; prices available from (615) 576-8401.

Available to the public from the National Technical Information Service, U.S. Department of Commerce, 5285 Port Royal Road, Springfield, VA 22161. 


\section{DISCLAIMER}

Portions of this document may be illegible in electronic image products. Images are produced from the best available original document. 


\section{Thirty-Year Solid Waste Generation Forecast by Treatability Group ${ }^{(U)}$}

Solid Waste Environmental Impact Statement Team

Prepared for the U.S. Department of Energy under contract no. DE-AC09-89SR18035 


\section{Contents}

\section{Executive Summary 1}

\section{Terms and Definitions 3}

Acronyms 3

Waste Category Terms and Definitions 4

Low-Level Waste 4

Mixed Waste 4

Hazardous Waste 4

Transuranic Waste 4

Treatability Group Terms and Definitions 4

Low-level Waste Treatability Groups 4

Mixed Waste Treatability Groups 5

Hazardous Waste Treatability Groups 7

Transuranic Waste Treatability Groups 7

Waste Stream Terms and Definitions 8

Low-Level Waste Streams 8

Mixed Waste Streams 9

Hazardous Waste Streams 10

Transuranic Waste Streams 11

\section{Background 13}

\section{Uncertainties and Assumptions 15}

\section{Uncertainties 15}

Assumptions 15

Waste Forecasts 15

Waste Generation Rates 15

Polychlorinated Biphenyl Wastes 15

Radiologically Contaminated Waste Oils 15

Mixed Waste Generation Volumes 15

Radioactive Materials Dispositions 16

Land Use (Long Term) 16

Low Activity Waste Generation 16

Decontamination and Decommissioning 16

Startup/Shutdown 16

Remediation 16

Remediation (Unknown) 16

\section{Operations 30-Year Forecast by Treatability Group 17 Low-Level Waste 17 \\ Job Control Waste 17 \\ Long Lived 17 \\ Tritiated 17}


Soils 17

Bulk 17

Mixed Waste 17

Composite Filters 18

Inorganic Debris 18

Soil 18

Aqueous Liquids 18

Organic Debris 18

Heterogeneous Debris 18

Land Disposal Restrictions Compliance 18

Lead 18

Organic Liquids 18

Organic Sludge 18

Consolidated Incineration Facility Ash18

Polychlorinated Biphenyls 18

Hazardous Waste 19

Polychlorinated Biphenyls 19

Heterogeneous Debris 19

Aqueous/Organic Liquids 19

Inorganic Debris 19

Soil 19

Lead 19

Organic Debris 19

TRU/TRU Mixed Waste 20

Low Activity Waste Requiring No Processing 20

Low Activity Waste Requiring Processing 20

High Activity Waste Requiring Processing 20

\section{Decontamination and Decommissioning 30-Year Forecast by Treatability Group 25}

Assumptions 25

Average Total Waste Volume (D\&D Activities) 25

Decontamination and Decommissioning to Greenfield 25

Contamination Due to Decontamination and Decommissioning 25

Average Total Waste Volume (to Foundation) 25

Average Total Waste Volume (Gutting) 25

Average Total Waste Volume (Removal Activities) 25

Data Manipulation 25

Waste Volume Generation Forecasts 25

Low-Level Waste (Taken to Foundation) 25

Mixed Waste (Taken to Foundation) 26

Hazardous Waste (Taken to Foundation) 26

Transuranic Waste (Taken to Foundation) 26

Low-Level Waste (Gutted) 26

Mixed Waste (Gutted) 26

Hazardous Waste (Gutted) 26

Transuranic Waste (Gutted) 26 
Waste Volumes Combined (Taken to Foundation and Gutted) 26

Decontamination and Decommissioning 30-Year Summary Tables 26

\section{Environmental Restoration 30-Year Forecast by Treatability} Group 31

Assumptions 31

Data Manipulation 31

Environmental Restoration 30-Year Summary Tables 31

\section{Operations, Decontamination and Decommissioning, and En- vironmental Restoration Summary Forecast By Treatability Group 37}

\section{References 43}

\section{Appendix A 45}

\section{List of Tables}

Table 1. Low-level Waste Operations Generation Forecast by Treatability Group 21

Table 2. Mixed Waste Operations Generation Forecast by Treatability Group 22

Table 3. Hazardous Waste Operations Generation Forecast by Treatability Group 23

Table 4. Transuranic Waste Operations Generation Forecast by Treatability Group 24

Table 5. Low-level Waste D\&D Forecast by Treatability Group 27

Table 6. Mixed Waste D\&D Forecast by Treatability Group 28

Table 7. Hazardous Waste D\&D Forecast by Treatability Group 29

Table 8. Transuranic Waste D\&D Forecast by Treatability Group 30

Table 9. Low-level Waste Environmental Restoration Forecast by Treatability Group 32

Table 10. Mixed Waste Environmental Restoration Forecast by Treatability Group 33 .

Table 11. Hazardous Waste Environmental Restoration by Treatability Group 34

Table 12. Transuranic Waste Environmental Restoration Forecast by Treatability Group 35

Table 13. Low-level Waste Summary Forecast by Treatability Group 38 
Table 14. Mixed Waste Summary Forecast by Treatability Group 39

Table 15. Hazardous Waste Summary Forecast by Treatability Group 40

Table 16. Transuanic Waste Summary Forecast by Treatability Group 41 


\section{Executive Summary}

This report is the second phase (Phase In) of the ThirtyYear Solid Waste Generation Forecast for Facilities at $S R S$ at the Savannah River Site (SRS). Phase I of the forecast, Thirty-Year Solid Waste Generation Forecast for Facilities at SRS (U) (Reference 4), forecasts the yearly quantities of low-level waste (LLW), hazardous, mixed, and transuranic (TRU) wastes to be generated over the next 30 years by operations, decontamination and decommissioning, (D\&D) and environmental restoration (ER) activities at SRS. This Phase II report also includes existing waste inventories that were not addressed in the Phase I report. Existing inventories include waste streams from continuing operations and stored wastes from discontinued operations.

The solid wastes stored or generated at SRS must be treated and disposed of in accordance with federal, state, and local laws and regulations. To evaluate, select, and justify the use of promising treatment technologies and evaluate the potential impacts to- the environment, the generic waste categories described in the Phase I report must be divided into smaller classifications with similar physical, chemical, and radiological characteristics. These classifications, defined as treatability groups, can be used in the Waste Management Environmental Impact Statement (WMEIS) process to evaluate treatment options.

This report provides a 30-year forecast by waste treatability group for operations, $D \& D$, and $E R$ activities. In addition, a 30-year forecast of waste streams has been provided for operations in Appendix A.

This Phase II report supports the in-depth options analysis for the WMEIS. 


\section{Terms and Definitions}

\section{Acronyms}

AEA Atomic Energy Act

CERCLA Comprehensive Environmental Response, Compensation and Liability Act

CFR Code of Federal Regulations

CIF Consolidated Incineration Facility

D\&D Decontamination and Decommissioning

DOE Department of Energy

DSTP Draft Site Treatment Plan

DWPF Defense Waste Processing Facility

EAV E-Area Vaults

EIS Environmental Impact Statement

EPA Environmental Protection Agency

ER Environmental Restoration

ETF Effluent Treatment Facility

FPTUR Filter Paper Take Up Rolls

FB F-Area Button

HEPA High Efficiency Particulate Air

HB H-Area Button

HW Hazardous Waste

ILW Intermediate Level Waste

IDW Investigation Derived Waste

ITP In-Tank Precipitation

LAW Low Activity Waste

LDR Land Disposal Restrictions

LHLW Liquid High-Level Waste

LLW Low-Level Waste

MW Mixed Waste
MWIR Mixed Waste Inventory Report

NPDES National Pollutant Discharge Elimination System

PCB Polychlorinated Biphenyls

PuFF Plutonium Fuel Fabrication

RBOF Receiving Basin for Offsite Fuels

RCA Radiologically Controlled Area

RCRA Resource Conservation and Recovery Act

RH Remote Handled

RRF Resin Regeneration Facility

SCDHEC South Carolina Department of Health and Environmental Control

SCHWMR South Carolina Hazardous Waste Management Regulations

SED Separations Equipment Demonstration

SRS Savannah River Site

SRTC Savannah River Technology Center

SWMD Solid Waste Management Department

TC Toxicity Characteristic

TCM Toxic Cleanup Material

TRU Transuranic

TSCA Toxic Substance Controls Act

TTA Thenoyl Trifluoroacetone

WIPP Waste Isolation Pilot Plant

WIPPWAC Waste Isolation Pilot Plant Waste Acceptance Criteria

WMEIS Waste Management Environmental Impact Statement

WSRC Westinghouse Savannah River Company 


\section{Waste Category Terms and Definitions}

\section{Low-Level Waste}

Waste that contains added radioactive isotopes and is not classified as high-level waste, transuranic waste, spent nuclear fuel, or Atomic Energy Act (AEA) 11e(2) byproduct material as defined in Department of Energy (DOE) Order 5820.2A (Reference 10). Within this report, all references to low-level waste (LLW) include low activity waste (LAW) and intermediate-level waste (ILW).

Low activity waste (LAW) is defined at SRS as solid betagamma emitting waste that radiates less than $200 \mathrm{mrad} / \mathrm{hr}$ or $200 \mathrm{mrem} / \mathrm{hr}$ at $5 \mathrm{~cm}$ from the unshielded container. (Examples of LAW are protective clothing, small equipment, plastic sheeting, gloves, soil, and suspect contaminated materials that were used within a radiologically contaminated area [RCA] and cannot be proven to be noncontaminated).

Intermediate-level waste (IIW) is a term specific to SRS for the higher activity fraction of low-level waste that contains beta-gamma emitters that produce a radiation dose rate equal to or greater than $200 \mathrm{mR} / \mathrm{hr}$ (or $200 \mathrm{mrad} / \mathrm{hr}$ or $200 \mathrm{mrem} / \mathrm{hr}$ ) at 5 centimeters from an unshielded container (Reference 10). Intermediate-level waste can also contain less than $10 \mathrm{nCi} / \mathrm{g}$ of transuranics. Any wastes with greater amounts of transuranics $(10-100 \mathrm{nCi} / \mathrm{q})$ are managed as TRU wastes.

Intermediate-level beta-gamma waste is typically contaminated equipment from the canyons or from Waste Management facilities, spent lithium-aluminum targets from Tritium operations, jumpers from F-Area and H-Area Tank Farm operations, reactor scrap, and irradiated reactor hardware that does not contain fuel.

\section{Mixed Waste}

Mixed waste (MW) is waste that is hazardous (as described by the South Carolina Hazardous Waste Management Regulation [SCHWMR] R.61-79.261.3) and radioactive. On May 1, 1987, the Department of Energy (DOE) issued a final interpretive byproduct material rule to clarify DOE's obligations under the Resource Conservation and Recovery Act (RCRA). The effect of the rule is that all DOE radioactive waste that is hazardous under the Resource Conservation and Recovery Act definition will be subject to regulation under both RCRA and AEA, with the hazardous components of the waste under the jurisdiction of the Environmental Protection Agency (EPA).
In the past, MW consisted primarily of tritiated mercury, tritiated oil, and scintillation fluids. Typical MW at SRS now includes radiologically contaminated lead, mercury, and cadmium.

\section{Hazardous Waste}

Hazardous waste (HW) is solid waste regulated by the Resource Conservation and Recovery Act and defined by SCHWMR as hazardous waste (Public Law 94-580) of 1976. Several EPA regulations (40 CFR 260 - 268 and others) implement RCRA. The South Carolina Department of Health and Environmental Control (SCDHEC) is authorized by EPA to administer RCRA, with the exception of the land disposal regulations (LDRs), via the SCHWMR.

Hazardous wastes are either "characteristic" or "listed". Hazardous waste is either ignitable, corrosive, reactive, toxic, or some combination.

\section{Transuranic Waste}

Without regard to source or form, transuranic (TRU) waste is waste contaminated with alpha-emitting transuranic radionuclides with half-lives greater than 20 years, and at concentrations greater than $100 \mathrm{nCi} / \mathrm{g}$ of waste matrix at the time of assay. The mass of the waste container and shielding will not be used in determining the TRU concentration. The limit was changed from $10 \mathrm{nCi} / \mathrm{g}$ to $100 \mathrm{nCi} / \mathrm{g}$ with DOE Order 5820.1 (dated September 30, 1992, implemented by SR Order 5820.1, dated March 24, 1983). However, SRS continues to manage waste containing between 10 and $100 \mathrm{nCi} / \mathrm{g}$ of transuranics as TRU waste until site-specific radiological performance assessments can be completed that will provide disposal limits for transuranic isotopes. TRU waste is primarily job control waste but may also include high efficiency particulate air (HEPA) filters, resins, and sludges.

\section{Treatability Group Terms and Definitions}

All wastes in a treatability group (a group/combination of characteristics such as physical, chemical, and/or radiological that describe a logical waste grouping) will be evaluated collectively when assessing the viability of various treatment technologies during the in-depth options analysis phase of the WMEIS.

\section{Low-Level Waste Treatability Groups}

The following treatability groups are a subset of the LLW category described and forecasted in the Thirty-Year Solid Waste Generation Forecast for Facilities at SRS. Treatability groups are mutually exclusive. Summing all wastes 
within low-level treatability groups will equal the total volume in the LLW category.

\section{Tritiated}

Operating, construction, and laboratory waste contaminated with tritium, in quantities equal to or greater than 10 Ci per container. Some examples include large and small metal equipment, protective clothing, gloves, etc. The special handling requirements for tritiated wastes make this a single treatability group regardless of physical, chemical, or other radiological characteristics.

\section{Long-lived}

Any low-level, non-tritiated (less than $10 \mathrm{Ci}$ of tritium per container) wasteform with large curie quantities of longlived nuclides (greater than 100-year half-life). The definition of large curie quantities is any value that exceeds the performance assessment restrictions of currently available disposal facilities. For example, spent deionizer resins containing large quantities of carbon-14 (half-life of 5730 years) are currently not suitable for shallow land disposal due to performance assessment criteria, and are considered long-lived waste.

\section{Bulk}

Large metal equipment, wood debris, metal debris, etc. that cannot be packaged in 55-gallon drums or radiologically contaminated B-25 boxes and do not meet the LLW treatability group definitions established above.

\section{Soils}

Soils and construction debris (e.g., asphalt, concrete, rock, rubble, metal debris, etc.) that have, or are suspected to have, radiological contamination and do not meet the LLW treatability group definitions established above.

\section{Job Control Waste}

Operating, construction, and laboratory waste that meets the DOE definition for LLW (e.g., small equipment, protective clothing, analytical waste, plastic sheeting, gloves, glass, metal, plastic, paper, wood, etc.) and does not meet the definition of any other LLW treatability group.

\section{Mixed Waste Treatability Groups}

The following treatability groups are a subset of the MW category described and forecasted in the Thirty-Year Solid Waste Generation Forecast for Facilities at SRS. Treatability groups are mutually exclusive. Summing all wastes within the mixed treatability groups will equal the total volume in the MW category.

\section{Land Disposal Restrictions}

Materials that will meet the disposal criteria in the LDRs defined by EPA in 40 CFR 268 or have an approved variance in their final, packaged form as received at the Solid Waste Disposal Facility (SWDF).

\section{Current}

Mixed waste streams that do not meet LDRs for which there is a current inventory, but no future generation is anticipated. This is not a true treatability group because of the many varied types of waste that fall into this category. This grouping was created for this effort, the WMEIS, because the waste streams included are currently in storage, have been evaluated in the Draft Site Treatment Plan for treatment, and will no longer be generated at SRS. Thus, treatment capacity and in-depth options analysis for future generation is not required. The treatments identified by the Draft Site Treatment Plan will be used.

\section{Ash Consolidated Incineration Facility}

Radiologically contaminated ash generated by the incineration of mixed wastes at the Consolidated Incineration Facility (CIF). These do not meet any of the mixed waste treatability group definitions established above. This ash is hazardous by application of the "derived-from" rule in SCHWMR R.61-79.261.3 and may also be characteristically hazardous for metals as defined in SCHWMR R.6179.261.3.

\section{Polychlorinated Biphenyls}

Radiologically contaminated wastes that are also contaminated with polychlorinated biphenyls $(\mathrm{PCB})$. Polychlorinated biphenyls wastes consist of rags, wipes, mops, cleanup materials, spill response cleanup materials, protective clothing, plastic, wood, glass, small pieces of metal equipment, and soils and construction debris contaminated with greater than $50 \mathrm{ppm}$ PCBs. Wastes generated as a result of PCB cleanup or PCB decontamination activities will be handled as PCB waste. These materials do not meet any of the mixed waste treatability group definitions established above. Although this is a Toxic Substance Controls Act (TSCA) waste and not a RCRA waste, it is included under mixed waste because of the similar regulatory requirements. 


\section{Heterogeneous Debris}

Radiologically contaminated materials that meet the definition of debris in the Debris Rule regulations, SCHWMR R.61-79.268.2, which are comprised of various organic and inorganic materials such as small pieces of equipment contaminated with characteristic, listed, or some combination of RCRA hazardous constituents as defined in SCHWMR R.61-79.261.3, and do not meet any of the MW treatability group definitions established above.

\section{Organic Debris}

Radiologically contaminated materials that meet the definition of debris in the Debris Rule regulations, SCHWMR R.61-79.268.2, comprised primarily of organic materials such as rags, mops, and like items contaminated with characteristic, listed, or some combination of RCRA hazardous constituents as defined in SCHWMR R.61-79.261.3. They do not meet any of the MW treatability group definitions established above.

\section{Inorganic Debris}

Radiologically contaminated materials that meet the definition of debris in the Debris Rule regulations, SCHWMR R.61-79.268.2, are comprised primarily of inorganic materials contaminated with characteristic, listed, or some combination of RCRA hazardous constituents as defined in SCHWMR R.61-79.261.3, and do not meet any of the MW treatability group definitions established above.

Concerning heterogeneous debris, organic debris, and inorganic debris, the EPA states a "prohibited hazardous debris is defined generally as solid material (that is not a processed waste) having a particle size of $60 \mathrm{~mm}$ or larger and that is intended for land disposal that exhibits a prohibited characteristic of hazardous waste or that is contaminated with a prohibited hazardous waste".

\section{Organic Sludge}

Radiologically contaminated materials that do not meet the definition of debris in the Debris Rule regulations, SCHWMR R.61-79.268.2, are comprised primarily of organic sludges contaminated with characteristic, listed, or some combination of RCRA hazardous constituents as defined in SCHWMR R.61-79.261.3, and do not meet any of the MW treatability group definitions established above.

\section{Organic Liquids}

A radiologically contaminated, pumpable, liquid waste, usually flammable, contaminated with characteristic, listed, or some combination of RCRA hazardous constituents as defined in SCHWMR R.61-79.261.3. These include oil, antifreeze, and like items-that may contain metals, suspended solids, and dissolved solids that do not meet the mixed waste treatability group definitions established above. All radiological oils are included in this group, both hazardous and nonhazardous.

Approximately half of the radiological oils will not require permitted storage; however, it is anticipated that all radiological oils will be treated in the same facility.

\section{Aqueous Liquids}

A radiologically contaminated, pumpable, liquid waste comprised primarily of water that may be contaminated with characteristic, listed, or some combination of RCRA hazardous constituents as defined in SCHWMR R.6179.261.3. This material may contain suspended solids, ionic compounds, dissolved solids, metals, and low concentrations of organic compounds and do not meet any of the MW treatability group definitions established above.

\section{Lead}

Radiologically contaminated lead or lead-bearing wastes that are characteristically hazardous for lead as defined in SCHWMR R.61-79.261.3, such as lead bricks, sheets, slag, lead-lined gloves, lead-lined aprons, lead waste from smelter operations, and other solid waste forms that do not meet any of the MW treatability group definitions established above.

\section{Composite Filters}

Various types of failed/spent radiologically contaminated filters that may also be contaminated with characteristic, listed, or some combination of RCRA hazardous constituents as defined in SCHWMR R.61-79.261.3 that do not meet any of the MW treatability group definitions established above.

\section{Soil}

Radiologically contaminated soils and construction debris including wood, concrete, asphalt, rubble, etc. that are also contaminated with characteristic, listed, or some combination of RCRA hazardous constituents as defined in SCHWMR R.61-79.261.3 and do not meet any of the MW treatability group definitions established above. 


\section{Hazardous Waste Treatability Groups}

The following treatability groups are a subset of the hazardous waste category described and forecasted in the Thirty-Year Solid Waste Generation Forecast for Facilities at SRS. Treatability groups are mutually exclusive. Summing all wastes within the hazardous treatability groups will equal the total volume in the HW category.

\section{Current}

Hazardous waste streams for which there is a current inventory, but no future generation is anticipated. This is not a true treatability group because of the many varied types of waste with different characteristics that fall into this category. This grouping was created for this effort because the waste streams in this category are in storage, have existing onsite or offsite treatment available, and will no longer be generated at SRS; therefore no future treatment capacity or option analysis is required.

\section{Polychlorinated Biphenyls}

Materials contaminated with PCBs that do not meet the definition of current waste. PCB wastes consist of rags, wipes, mops, cleanup materials, spill response cleanup materials, protective clothing, plastic, wood, glass, small pieces of metal equipment and soils and construction debris contaminated with greater than $50 \mathrm{ppm}$ PCBs. Waste generated as a result of the cleanup of $\mathrm{PCB}$ decontamination activities will be handled as PCB wastes. Although this is a TSCA waste and not a RCRA waste, it is included under MW because of the similar regulatory requirements.

\section{Heterogeneous Debris}

Materials that may meet the definition of debris in the Debris Rule regulations 57 FR 37194, SCHWMR R.6179.268.2, are comprised of various organic and inorganic materials contaminated with characteristic, listed, or some combination of RCRA hazardous constituents as defined in SCHWMR R.61-79.261.3, and do not meet any of the HW treatability group definitions established above.

\section{Organic Debris}

Materials that meet the definition of debris in the Debris Rule regulations, SCHWMR R.61-79.268.2, comprised primarily of organic materials contaminated with characteristic, listed, or some combination of RCRA hazardous constituents as defined in SCHWMR R.61-79.261.3 and are wastes that do not meet any of the HW treatability group definitions established above.

\section{Inorganic Debris}

Materials that may meet the definition of debris in the Debris Rule regulations, SCHWMR R.61-79.268.2, are comprised primarily of inorganic materials contaminated with characteristic, listed, or some combination of RCRA hazardous constituents as defined in SCHWMR R.6179.261.3, and do not meet any of the HW treatability group definitions established above.

Concerning heterogeneous debris, organic debris, and inorganic debris, the EPA states a "prohibited hazardous debris is defined generally as solid material (that is not a processed waste) having a particle size of $60 \mathrm{~mm}$ or larger and that is intended for land disposal that exhibits a prohibited characteristic of hazardous waste or that is contaminated with a prohibited hazardous waste".

\section{Aqueous/Organic Liquid}

A pumpable liquid waste, contaminated with characteristic, listed, or some combination of RCRA hazardous constituents as defined in SCHWMR R.61-79.261.3. These liquids may contain metals, suspended solids, or dissolved solids and are wastes that do not meet any of the hazardous waste treatability group definitions established above.

\section{Lead}

Predominantly lead or lead-bearing wastes that are characteristically hazardous for lead as defined in SCHWMR R.61-79.261.3 such as lead bricks, sheets, slag, lead-lined gloves, lead-lined aprons, lead waste from smelter operations, and other solid wasteforms that do not meet any of the HW treatability group definitions established above.

\section{Soil}

Soils and construction debris including wood, concrete, asphalt, rubble, and like items contaminated with characteristic, listed, or some combination of RCRA hazardous constituents as defined in SCHWMR R.61-79.261.3 and other RCRA hazardous materials that do not meet the definition of any other HW treatability group.

\section{Transuranic Waste Treatability Groups}

The following treatability groups are a subset of the TRU waste category described and forecasted in the Thirty-Year Solid Waste Generation Forecast for Facilities at SRS. Treatability groups are mutually exclusive. Summing all wastes within the TRU treatability groups will equal the total volume in the TRU waste category. 


\section{Low Activity Waste-Not Requiring Processing}

Non-RCRA hazardous job control waste from plutonium processing facilities suspected of containing TRU isotopes between 10 and $100 \mathrm{nCi} / \mathrm{gm}$. This material is managed as TRU waste and will require assay analysis to determine the actual isotopic concentrations prior to reclassification as low-level waste or treatment to meet the Waste Isolation Pilot Plant Waste Acceptance Criteria (WIPPWAC).

\section{Low Activity Waste-Requiring Processing}

Job control waste from Pu processing facilities, containing $>10 \mathrm{nCi} / \mathrm{g}$ and $<0.5 \mathrm{Ci} /$ package of TRU isotopes that may also be contaminated with characteristic, listed, or some combination of RCRA hazardous constituents as defined in SCHWMR R.61-79.260. This group also includes nonRCRA hazardous job control waste from plutonium processing facilities suspected of containing TRU isotopes $>100 \mathrm{nCi} / \mathrm{gm}$ but less than $0.5 \mathrm{Ci} /$ package.

Some of the RCRA hazardous material is managed as TRU waste and will require assay analysis to determine the actual isotopic concentrations. All RCRA hazardous waste that contains $<100 \mathrm{nCi} / \mathrm{g}$ will require $\mathrm{LDR}$ treatment to meet the disposal requirements for mixed waste disposal facilities other than WIPP.

All (both RCRA the hazardous and non-RCRA hazardous) $>100 \mathrm{nCi} / \mathrm{gm}$ but less than $0.5 \mathrm{Ci} /$ package waste will require further characterization and processing to meet Waste Isolation Pilot Plant Waste Acceptance Criteria (WIPPWAC).

\section{High Activity Waste-Requiring Processing}

All (both RCRA the hazardous and non-RCRA hazardous) greater than $0.5 \mathrm{Ci}$ /package waste requiring further characterization and processing to meet WIPPWAC requirements. Any wastes that can be reclassified as less than 100 $\mathrm{nCi} / \mathrm{g}$ during processing will require treatment to $\mathrm{LDR}$ requirements for disposal as mixed waste or to LLW criteria for onsite disposal.

\section{Waste Stream Terms and Definitions}

The following waste stream definitions describe the current waste inventories and postulated future wastes generated by normal operations. There is insufficient data to describe waste from future D\&D and ER activities in any more detail than the treatability group.

\section{Low-Level Waste Streams}

Spent Deionizer Resin

Resin from reactor deionizers.

Tritiated Intermediate Activity Job Conntrol Waste

Job control wastes that have beta-gamma emitters producing a radiation dose rate equal to or greater than $200 \mathrm{mR} /$ hr (or $200 \mathrm{mrad} / \mathrm{hr}$ or $200 \mathrm{mrem} / \mathrm{hr}$ ) at $5 \mathrm{~cm}$ from an unshielded container that also contains less than $10 \mathrm{nCi}$ of tritium per gram.

\section{Low Activity Job Control Waste}

Job control waste radiating less than $200 \mathrm{mR} / \mathrm{hr}(200$ $\mathrm{mrad} / \mathrm{hr}$ or $200 \mathrm{mrem} / \mathrm{hr}$ ) at $5 \mathrm{~cm}$ from an unshielded container.

\section{Intermediate Activity Job Control Waste}

Job control waste containing beta-gamma emitters that produce a radiation dose rate equal to or greater than 200 $\mathrm{mR} / \mathrm{hr}$ (or $200 \mathrm{mrad} / \mathrm{hr}$ or $200 \mathrm{mrem} / \mathrm{hr}$ ) at $5 \mathrm{~cm}$ from an unshielded container.

\section{Shipments from Offsite}

Job control waste being produced from naval reactors and shipped to SRS for disposal. This waste has already been compacted and does not require additional treatment.

\section{Low Activity Equipment}

Large contaminated (radiating less than $200 \mathrm{mR} / \mathrm{hr}, 200$ $\mathrm{mrad} / \mathrm{hr}$ or $200 \mathrm{mrem} / \mathrm{hr}$ at $5 \mathrm{~cm}$ from an unshielded container) metal equipment that is too large to be packaged in B-25 boxes.

\section{Naval Hardware}

Large reactor components/equipment from the Naval Reactors program.

\section{Low Activity Soil}

Soils radiating less than $200 \mathrm{mR} / \mathrm{hr}(200 \mathrm{mrad} / \mathrm{hr}$ or 200 $\mathrm{mrem} / \mathrm{hr}$ ) at $5 \mathrm{~cm}$ from an unshielded container.

\section{Suspect Soil}

Soils from an RCA that may or may not be contaminated. 


\section{Mixed Waste Streams}

\section{Current}

Mixed waste streams that do not meet LDRs for which there is a current inventory, but no future generation is anticipated. This is not a true treatability group because of the many varied types of waste that fall into this category. This grouping was created for this effort, the WMEIS, because the waste streams that are included in this group are currently in storage, have been evaluated in the DSTP for treatment, and will no longer be generated at SRS, thus treatment capacity and in-depth options analysis for future generation is not required. The treatments identified in the Draft Site Treatment Plan will be used for these streams.

\section{Polychlorinated Biphenyls}

Radiologically contaminated wastes that are also contaminated with PCBs. PCB wastes consist of rags, wipes, mops, cleanup materials, spill response cleanup materials, protective clothing, plastic, wood, glass, small pieces of metal equipment and soils and construction debris contaminated with greater than $50 \mathrm{ppm}$ PCBs. Waste generated as a result of $P C B$ cleanup of PCB decontamination activities will be handled as PCB waste. Although this is a TSCA waste and not a RCRA waste, it is included under MW because of the similar regulatory requirements.

\section{Filters}

Various types of failed/spent filters, radiologically contaminated, that may also be contaminated with characteristic, listed, or some combination of RCRA hazardous constituents.

\section{Glass Debris}

Glass waste, which includes laboratory waste such as test tubes, etc., that is radiologically contaminated and may be contaminated with characteristic, listed, or some combination of RCRA hazardous constituents as defined in SCHWMR R.61-79.261.3.

\section{Mercury-Contaminated Equipment}

Equipment and pieces of equipment that are radiologically contaminated and characteristically hazardous for mercury as defined in SCHWMR R.61-79.261.3.

\section{Soils-Environmental Restoration Solids and Mud}

Radiologically contaminated soil and mud generated from ER activities. This waste may be contaminated with char- acteristic, listed, or some combination of RCRA hazardous constituents as defined in SCHWMR R.61-79.261.3.

\section{Aqueous Liquids}

Miscellaneous aqueous liquid waste generated across the Site that may be contaminated with characteristic, listed, or some combination of RCRA hazardous constituents as defined in SCHWMR R.61-79.261.3. The largest portion of this waste stream is made up of ER wastes-purge and rinsate waters.

\section{Consolidated Incineration Facility Blowdown}

A byproduct of the incinerator's air pollution control system, this is an aqueous, radiologically contaminated, chloride liquid that is considered RCRA hazardous by application of the derived-from rule in SCHWMR R.6179.261.3 and may also be characteristic hazardous for metals as defined in SCHWMR R.61-79.261.3.

\section{Toxic Cleanup Materials}

Radiologically contaminated materials comprised of debris such as rags, mops, protective clothing, and plastic huts that may be contaminated with characteristic, listed, or some combination of RCRA hazardous constituents as defined in SCHWMR R.61-79.261.3.

\section{Radiologically Contaminated Solvents}

Radiologically contaminated materials comprised primarily of debris such as rags that are contaminated with RCRA-listed solvents and other RCRA hazardous constituents.

\section{Organic Sludge}

Radiologically contaminated materials-that do not meet the definition of debris in the Debris Rule regulations, SCHWMR R.61-79.268.2, and are comprised primarily of organic sludges contaminated with characteristic, listed, or some combination of RCRA hazardous constituents as defined in SCHWMR R.61-79.261.3.

\section{Heterogeneous Debris}

Radiologically contaminated materials that meet the definition of debris in the Debris Rule regulations, SCHWMR R.61-79.268.2, are comprised of various organic and inorganic materials such as batteries, small pieces of equipment, and protective equipment contaminated with characteristic, listed, or some combination of RCRA haz- 
ardous constituents as defined in SCHWMR R.6179.261.3.

\section{Gold Traps}

Used gold traps from the Tritium facility that are considered RCRA hazardous as defined in SCHWMR R.6179.261.3 due to the presence of mercury. The mercury is amalgamated on the gold traps. Interpretation received from EPA verifies that the amalgamated mercury meets the treatment standard, therefore, when packaged, the waste may be disposed of in a RCRA-permitted disposal facility.

\section{In-Tank Precipitation Filters}

Failed filters from ITP that are considered RCRA hazardous as defined in SCHWMR R.61-79.261.3 because of the presence of benzene and possibly metals. Following in situ oxalic acid washing and subsequent placement into an engineered box under the authority of a treatability variance approved by EPA, the filters meet the alternate treatment for LDR and may be disposed of in a RCRApermitted disposal facility.

\section{M-Area Glass}

Stabilized material from the M-Area vendor vitrification process. This radiologically contaminated material will meet the EPA LDRs in 40 CFR 268 and may be disposed of in a RCRA-permitted disposal facility.

\section{Lead}

Radiologically contaminated lead and lead pieces used primarily for shielding purposes. This waste is considered characteristically hazardous for lead as defined in SCHWMR R.61-79.261.3.

\section{Defense Waste Processing Facility (DWPF) Benzene}

A radiologically contaminated, liquid, organic waste generated during DWPF operations that is considered characteristically hazardous for benzene as defined in SCHWMR R.61-79.261.3.

\section{Paints and Thinners}

Radiologically contaminated solids and sludges from paints and thinners generated across the Site that may be contaminated with characteristic, listed, or some combination of RCRA hazardous constituents as defined in SCHWMR R.61-79.261.3.

\section{Radioactive Oils}

Radiologically contaminated oils that may also be contaminated with characteristic, listed, or some combination of RCRA hazardous constituents as defined in SCHWMR R.61-79.261.3. This stream also includes radiologically contaminated oils that are not considered RCRA hazardous by SCDHEC. This consolidation is for treatment anticipated to be similar. Approximately half of the radiological oils will not require RCRA-permitted storage.

\section{Freon/Oil/Organic Liquid}

Radiologically contaminated freon and oil generated across the Site from refrigeration and cooling units that may be contaminated with characteristic, listed, or some combination of RCRA hazardous constituents as defined in SCHWMR R.61-79.261.3. This waste stream includes other miscellaneous organic liquids that do not meet the other organic liquid waste stream definitions.

\section{Consolidated Incineration Facility Ash}

This waste stream consists of radiologically contaminated ash generated by the incineration of mixed wastes at the consolidated incineration facility. This ash is hazardous by application of the derived-from rule in SCHWMR R.6179.261.3 and may also be characteristic hazardous for metals as defined in SCHWMR R.61-79.261.3.

\section{Hazardous Waste Streams}

\section{Current}

Hazardous waste streams for which there is a current inventory, but no future generation is anticipated. This is not a true treatability group because of the varied types of waste with different characteristics that fall into this category. This grouping was created for this effort because the waste streams in this category are in storage, have existing onsite or offsite treatment available, and will no longer be generated at SRS; therefore, no future treatment capacity or option analysis is required.

\section{Polychlorinated Biphenyls}

Wastes contaminated with PCBs. PCB wastes consist of rags, wipes, mops, cleanup materials, spill response cleanup materials, protective clothing, plastic, wood, glass, small pieces of metal equipment, and soils and construction debris contaminated with greater than $50 \mathrm{ppm}$ PCBs. Waste generated as a result of PCB cleanup of PCB decontamination activities will be handled as $\mathrm{PCB}$ waste. Although this is a TSCA waste and not a RCRA waste, it 
is included under hazardous waste because of the similar regulatory requirements.

\section{Miscellaneous TC Wastes-Solid}

Solid wastes contaminated with characteristic RCRA hazardous constituents as defined in SCHWMR R.6179.261.3.

Batteries-used batteries considered characteristically hazardous as defined in SCHWMR R.61-79.261.3 that may be acidic or alkaline and may contain lead, mercury, and cadmium.

Miscellaneous Toxicity Characteristic (TC) WastesLiquid-liquid wastes contaminated with characteristic RCRA hazardous constituents as defined in SCHWMR R.61-79.261.3.

Miscellaneous Solvents-miscellaneous organic solvents contaminated with characteristic, listed, or some combination of RCRA hazardous constituents as defined in SCHWMR R.61-79.261.3.

Ignitable and Miscellaneous TC-miscellaneous and ignitable organic or aqueous liquids contaminated with characteristic, listed, or some combination of RCRA hazardous constituents as defined in SCHWMR R.6179.261.3.

Spent Varnish and Paint-used or spent varnish and paint considered characteristic, listed, or some combination of RCRA hazardous waste as defined in SCHWMR R.6179.261.3.

Low Mercury Wastes (glass)-glass waste such as used light bulbs that may be considered characteristically hazardous for mercury as defined in SCHWMR R.61-79261.3.

Contaminated Soil-soils contaminated with characteristic, listed, or some combination of RCRA hazardous constituents as defined in SCHWMR R.61-79.261.3.

\section{Lead Smelter and Soil Waste}

Lead-bearing wastes and lead contaminated soils that are considered characteristically hazardous for lead as defined in SCHWMR R.61-79-261.3.

\section{Halogenated Solvents (Toxic Cleanup Materials)}

Toxic cleanup materials that may be contaminated with characteristic, listed or some combination of RCRA haz- ardous constituents as defined in SCHWMR R.6179.261.3.

\section{Transuranic Waste Streams}

\section{$<100 \mathrm{nCi} / \mathrm{gm}$ Waste Being Managed as TRU}

Miscellaneous, non-RCRA hazardous waste such as job control waste, protective clothing, cloth, paper, rubber, swipes, rags, booties, glassware, small metal objects and pieces of equipment, wood, plastic, etc. from TRU-generating facilities. This waste is contaminated with TRU isotopes in quantities suspected to be $<100 \mathrm{nCi} / \mathrm{gm}$.

\section{$<100 \mathrm{nCi}$ /gm Mixed Waste Being Managed as TRU}

Miscellaneous waste such as job control waste, protective clothing, cloth, paper, rubber, swipes, rags, booties, glassware, small metal objects and pieces of equipment, wood, or plastic from TRU-generating facilities. This waste is contaminated with TRU isotopes in quantities suspected to be $<100 \mathrm{nCi} / \mathrm{gm}$ and that may also be hazardous as defined in SCHWMR R.61-79.261.3 because of the presence of listed or characteristic materials or because of application of the derived from rule in SCHWMR R.61-79.261.3. (See Reference 8, Waste Streams SR-W025 and SR-W033 for more information.)

\section{$>100 \mathrm{nCi} / \mathrm{gm} \&<0.5 \mathrm{Ci}$ TRU Waste}

Miscellaneous non-RCRA waste such as job control waste including protective clothing, cloth, paper, rubber, swipes, rags, booties, glassware, small metal objects, and pieces of equipment, wood, and plastic from TRU-generating facilities. This waste is contaminated with TRU isotopes in quantities between $100 \mathrm{nCi} / g m$ and $<0.5 \mathrm{Ci} /$ package.

\section{$>100 \mathrm{nCi} / \mathrm{gm} \&<0.5 \mathrm{Ci}$ TRU Mixed Waste}

Miscellaneous waste such as job control waste, including protective clothing, cloth, paper, rubber, swipes, rags, booties, glassware, small metal objects, and pieces of equipment, wood, and plastic from TRU-generating facilities. This waste is contaminated with TRU isotopes in quantities suspected to be between $100 \mathrm{nCi} / g m$ and $<0.5$ Ci/package that may also be RCRA hazardous as defined in SCHWMR R.61-79.260 because of the presence of listed or characteristic materials or because of application of the derived from rule defined in SCHWMR R.6179.261.3. (See Reference 8, Waste Streams SR-W026 and SR-W027 for more information.) 


\section{0.5 Ci TRU Waste}

Miscellaneous non-RCRA waste such as job control waste including protective clothing, cloth, paper, rubber, swipes, rags, booties, glassware, small metal objects, and pieces of equipment, wood, or plastic from TRU-generating facilities. This waste is suspected to be contaminated with TRU isotopes in quantities greater than or equal to $0.5 \mathrm{Ci} /$ package.

\section{z 0.5 Ci TRU Mixed Waste}

Miscellaneous waste such as job control waste including protective clothing, cloth, paper, rubber, swipes, rags, booties, glassware, small metal objects, and pieces of equipment, wood, plastic, etc. from TRU-generating facilities. This waste is suspected to be contaminated with TRU isotopes in quantities greater than or equal to $0.5 \mathrm{Ci} /$ package that may also be RCRA hazardous as defined in SCHWMR R.61-79.261.3 because of the presence of listed or characteristic materials or because of application of the derived from rule defined in SCHWMR R.6179.261.3. (See Reference 8, Waste Streams SR-W026 and SR-W027 for more information.)

\section{Bulky Equipment and Miscellaneous Items}

Miscellaneous RCRA waste including large pieces of equipment, pumps, duct work, gloveboxes, and filters that consists primarily of metal, wood, plastic, and glass from TRU-generating facilities. This TRU-contaminated waste is not packaged in 55-gallon drums.

\section{Mixed Waste Bulky Equipment}

Miscellaneous, non-RCRA waste including large pieces of equipment, pumps, duct work, gloveboxes, and filters that consists primarily of metal, wood, plastic and glass from TRU-generating facilities. This TRU-contaminated waste is not packaged in 55-gallon drums. It may also be RCRA hazardous as defined in SCHWMR R.61-79.261.3 because of the presence of listed or characteristic materials or the application of the derived-from rule defined in SCHWMR R.61-79.261.3. (See Reference 8, Wäste Streams SRW026 and SR-W027 for more information.)

\section{Remote Handled (RH) TRU Waste}

Miscellaneous, non-RCRA waste including filters, equipment, pumps, duct work, and gloveboxes consisting primarily of metal, wood, plastic, and glass and job control waste including protective clothing, cloth, paper, rubber, swipes, rags, booties, glassware, small metal objects, and pieces of equipment, wood, and plastic from TRU-generating facilities. This waste is contaminated with TRU isotopes and has a radiation dose rate of greater than 200 $\mathrm{mrem} / \mathrm{hr}$ as defined in the WIPPWAC.

Remote Handled (RH) Mixed TRU Waste-miscellaneous waste including filters, equipment, pumps, duct work, or gloveboxes consisting primarily of metal, wood, plastic and glass and job control waste including protective clothing, cloth, paper, rubber, swipes, rags, booties, glassware, small metal objects, and pieces of equipment, wood, and plastic from TRU-generating facilities. This waste is contaminated with TRU isotopes and has a radiation dose rate of greater than $200 \mathrm{mrem} / \mathrm{hr}$ as defined in the WIPPWAC and may be RCRA hazardous as defined in SCHWMR R.61-79.261.3 because of the presence of listed or characteristic materials or because of application of the derived-from rule defined in SCHWMR R.6179.261.3. 


\section{Background}

This report is Phase II of the Thirty-Year Solid Waste Generation Forecast for Facilities at SRS. Phase I of the forecast, Thirty-Year Solid Waste Generation Forecast for Facilities at SRS $(U)$ (Reference 4), forecasts the yearly quantities of LLW, hazardous, mixed, and TRU wastes generated over the next 30 years by operations, D\&D, and ER activities at SRS.

The solid wastes stored or generated at SRS must be treated and disposed of in accordance with federal, state, and local laws and regulations. To evaluate, select, and justify the use of promising treatment technologies and to evaluate the potential impacts to the environment, the generic waste categories described in the Phase I report must be divided into smaller classifications with similar physical, chemical, and radiological characteristics. These classifications, defined as treatability groups, can be used in the WMEIS process to evaluate treatment options. The methodology used to categorize the SRS Solid Waste streams into treatability groups is based on the premise that the key information necessary for identifying like treatments can be discerned from the radiological, physical, and chemical properties of the wastes and their contaminants.

For waste streams placed into the treatability groups by the Draft Site Treatment Plan Program, the DSTP treatability groupings are generally used. For hazardous wastes, treatability groups are consistent with the DSTP treatability groups for mixed waste streams.

This report provides a 30-year forecast by waste treatability group for operations, $D \& D$, and ER activities. Current inventories of waste are also reported. A 30 -year forecast by waste stream is provided for operations in Appendix A.

The remainder of this report documents the assumptions and decision-making process used in generating the 30 .year waste forecast by treatability group. 


\section{Uncertainties and Assumptions}

\section{Uncertainties}

- The effect that future waste certification and treatment requirements will have on waste generation

- The effect of higher waste generation because of more rigid compliance, disciplines, operation, etc., than in the past

- The effect of delays in funding facility shutdowns, transition, $D \& D$, and remediation

- The effect of unspecified requirements for shutdowns, transitions, $\mathrm{D} \& \mathrm{D}$, and remediation

- The effect of using contractors rather than SRS workers

- The effect of SRS experience base expansion on outyear ER and D\&D

- The effect of new technology development for D\&D and ER

- The effect of future changes to the Site mission

- The effect of regulatory and legal requirements that are new or changing.

\section{Assumptions}

\section{Waste Forecasts}

All waste forecasts assume an effective facility waste minimization program in accordance with the Site Waste Minimization Plan during the next 30 years (Reference 12). There will not be any radical technological developments that will result in a significant decrease of waste generated.

\section{Waste Generation Rates}

Projected waste generation rates for the expected case are based on current regulatory and DOE requirements, available technologies, and waste certification requirements.

\section{Polychlorinated Biphenyl Wastes}

For the purposes of this report, nonradioactive PCB wastes will be treated as hazardous waste. Radiologically contaminated PCB wastes will be treated as mixed waste.

\section{Radiologically Contaminated Waste Oils}

For the purposes of this report, all radiologically contaminated waste oils are included in the mixed waste forecast volumes because it is anticipated that all radiologically contaminated oils will be disposed of in the same manner.

\section{Mixed Waste Generation Volumes}

The mixed waste generation volumes in this forecast include all mixed wastes targeted for management by the Solid Waste Management Department and waste generated by routine environmental restoration activities. This volumes differs from the data in Mixed Waste Inventory Report (MWIR) because MWIR does not currently include waste generated from routine environmental restoration activities.

Wastes included in this report, which are not included in the MWIR, include the following:

- ER wastes such as soils, rinsate water, purge water, and personal protective equipment. These wastes are included in this report for two reasons: (1) Although a portion of these wastes are treated in existing facilities, they are radiologically contaminated wastes that contain low levels of hazardous constituents. (2) In a conservative approach, regulations and the final approved Investigative Derived Waste (IDW) Plan, which is currently with the state regulators for review, could require these wastes to be handled as MW.

- Glass debris generated from within RCAs. This includes wastes generated within labs.

- Heterogeneous debris that encompasses the future generation of a large variety of wastes (including ER wastes identified above) currently unspecified in contaminates or form. It is expected that these wastes, when further characterized, can be treated in a similar manner as those wastes under other categories of inorganic and organic wastes.

Wastes included in the MWIR that are not included in this report include Savannah River Technology Center (SRTC) low and high activity liquid wastes that are stored and treated in SRTC wastewater treatment tanks. These wastes were never intended to be handled at SWMD facilities and are addressed solely in the Draft Site Treatment Plan. It is assumed that the storage tanks, which are located in F Canyon, will remain operational past F-Canyon shutdown until other storage facilities can be provided.

\section{Radioactive Materials Dispositions}

Key guidance assumptions for the radioactive materials dispositions are: 
- SRS will continue to be government-owned and contractor-operated and will provide land for DOE-related activities with adequate isolation from population centers.

- Surplus Defense Programs (DP) facilities will be deactivated and undergo D\&D.

- The Site will continue to support environmental ecological research, balanced forest management, and historical and archeological programs.

\section{Land Use (Long Term)}

For long-range planning of land use, it is assumed that the central site area is to be used for continued Defense Program activities and for the disposal and monitoring of waste materials that remain on site. This will exclude the use of the surface, subsurface, and groundwater in the central industrial area from unrestricted use in the future. The central industrial area is centered on the Separations and Solid Waste Complex Areas and extends to the reactor areas. The remaining site boundary surface and subsurface soil regions (SRTC, 300 Area, 400 Area, TNX, the Reactors, and other miscellaneous areas) at the plant perimeter will be remediated as necessary to allow unrestricted use. The specific level of cleanup of the surface, subsurface, and groundwater in these perimeter areas will be determined through processes established through RCRA.

\section{Low Activity Waste Generation}

Low activity waste generation figures do not reflect compaction prior to disposal.

Decisions regarding the regulatory requirements/handling of ER wastes will require less than $20 \%$ of the waste generated from environmental restoration activities (soils and mud) to be handled as RCRA hazardous waste. All purged water from wells will be handled as RCRA hazardous waste. Monitoring well sampling volumes will be reduced by $50 \%$ of current volumes.

\section{Decontamination and Decommissioning}

In the 30-year period, the following facilities will not undergo D\&D:

- Defense Waste Processing Facility (DWPF)

- Z-Area Saltstone Facility

- Effluent Treatment Facility (ETF)

- In-Tank Precipitation (ITP) Facility
- Savannah River Technology Center (except for Separations Equipment Demonstration facility)

- Replacement Tritium Facility

- Type III waste tanks

- New Special Recovery Facility of 221 FB-Line

- 484-D Powerhouse Facility, 483-1D Water Treatment Facility, and support buildings

- Consolidated Incineration Facility

- Analytical Labs (excluding 772-D)

- Burial Grounds Facilities

\section{Startup/Shutdown}

It is assumed that the following major facilities will start up or shut down during the following years:

\section{Startup}

FY 96 Defense Waste Processing Facility Consolidated Incineration Facility

\section{Shutdown}

$\begin{array}{ll}\text { FY 97 } & \text { Reactors/D Area } \\ \text { FY 98 } & \begin{array}{l}\text { 772-D Laboratory } \\ \text { Reactor Materials }\end{array} \\ \text { FY 99 } & \text { TNX } \\ \text { FY 03 } & \text { HB Line } \\ & \text { F Canyon } \\ & \text { FB Line } \\ \text { FY 05 } & \text { RBOF/RRF } \\ & \text { H Canyon } \\ \text { FY 13 } & \text { 235-F PuFF and Thoria Line }\end{array}$

\section{Remediation}

It is assumed that for all sites/facilities/spills identified in Appendices $\mathrm{C}$ and $\mathrm{H}$ of the FFA (Reference 13), some form of remediation will occur. Remediation may consist of in situ treatment, waste removal, or capping and site stabilization. For all ER remediation activities, the sites or facilities undergoing remediation will be cleaned up to the Applicable, Relevant, and Appropriate Requirements (ARARs).

\section{Remediation (Unknown)}

Upon further investigation, some of the sites, facilities, or spills identified in appendix of the FFA will require some form of remediation. 


\section{Operations 30-Year Forecast by Treatability Group}

\section{Low-Level Waste}

The following treatability groups for low-level waste were established based on the radiological and physical characteristics of the waste. These groups identify treatment needs and/or disposal options. Under each treatability group is a listing of the applicable LLW streams.

\section{Job Control Waste}

- Low activity job control

- Intermediate activity job control

- Shipments from offsite

\section{Long Lived}

- Spent deionizer resins

\section{Tritiated}

- Tritiated intermediate activity job control

Soils

- Low activity soil

- Suspect soil

Bulk

- Low activity equipment

- Naval hardware

The present low-level waste current inventory consists only of naval components from the D \& D of naval fuel vessels. The naval components are considered low activity waste; however, because of the carbon-14 content, more evaluation will be required to determine if it is correctly classified.

The low-level waste operations forecast volumes were obtained from information in Reference 4. Descriptions of the waste shown in Appendices A and B of Reference 4 were used to place the waste into treatability groups and waste streams. In addition to the assumptions made in Reference 4, the following assumption was made to place the forecasted waste volumes into treatability groups and waste streams:

- Appendix B of Reference 4 shows $60 \mathrm{~m}^{3}$ of suspect soil being generated in years 1995-1997. It was assumed that the LLW volumes shown for the subsequent years also contains $60 \mathrm{~m}^{3}$ of suspect soil.

The forecast by the treatability group is found in Table 1. The waste stream forecast is found in Appendix A, Table A.1.

\section{Mixed Waste}

The MW treatability groups identified for the EIS are similar to those in the Mixed Waste Inventory Report. These groups are consistent with the DOE guidance on mixed waste treatability groups. This grouping was based on similar chemical and physical characteristics.

The SRS. Mixed Waste Inventory Report (Reference 8) includes some liquid high-level waste (LHLW) and TRU waste streams. For the EIS, these waste streams are appropriately addressed for treatability groups in the LHLW and TRU waste categories.

The mixed waste annual generation, as shown on the Mixed Waste 30-Year Forecast tables, was compiled following the method described below. The current inventory was obtained from the Mixed Waste Inventory Report (MWIR), combining the individual waste stream volumes to obtain generation rates for the treatability groups identified in the attached table. These volumes include the inventory listed as of September 30, 1993. The particularly small volume of waste received at the mixed waste storage buildings since September 1993 is not accounted for in the current inventory.

Most of the future generation volumes were obtained from the Thirty-Year Solid Waste Generation Forecast for Facilities at SRS (Reference 4). These numbers were used rather than the future generation rates identified in the MWIR because they more accurately reflect the waste volumes and the breakdown of future mixed waste generation at SRS. For the first three-year period, 1995-1997, waste generators gave descriptions of the waste types and annual volumes anticipated to be generated. The descriptions and generation rates provided in Reference 4 were used to place the volumes into the already identified treatability groups.

Based on input from the Environmental Restoration Department, regulations will require less than $20 \%$ of the waste generated from environmental restoration activities (soils and mud) to be handled as RCRA hazardous waste. 
All purged water from wells will be handled as RCRA hazardous waste. Monitoring well sampling volumes will be reduced by $50 \%$ of current volumes.

The following treatability groups for mixed waste were established based on the radiological and physical characteristics of the waste. These groups include waste with similar physical and chemical characteristics. Under each treatability group is a listing of the applicable mixed waste streams.

\section{Composite Filters}

- Filters

\section{Inorganic Debris}

- Glass debris

- Mercury-contaminated equipment

\section{Soil}

- Soils-Environmental Restoration solids and mud

\section{Aqueous Liquids}

- Aqueous liquids

- CIF blowdown

\section{Organic Debris}

- Toxic cleanup material

- Radiologically contaminated solvents

\section{Heterogeneous Debris}

- Heterogeneous debris

\section{Land Disposal Restrictions Compliance}

- Gold traps

- ITP filters

- M-Area glass

\section{Lead}

- Lead

\section{Organic Liquids}

- DWPF benzene

- Freon/oil/organic liquids

- Radioactive oils
Organic Sludge

- Organic sludge

- Paints and thinners

\section{Consolidated Incineration Facility Ash}

- CIF ash

\section{Polychlorinated Biphenyls}

- Radiologically contaminated PCBs

An additional treatability group identified in the tables as "Current" in the column headings is comprised of the total volume of wastes that have a current inventory onsite but are not anticipated to have any future generation. These wastes have been identified to accurately represent the current inventory of wastes on site; however, their individual characteristics and volumes are not identified here. The treatments identified in the Draft Site Treatment Plan will be used for all waste streams identified in this group. The following is a list of those waste streams identified in the MWIR that are included in this group:

- Filter paper take up rolls (FPTUR)

- Cadmium-coated HEPA filters

- Scintillation solution

- Spent methanol solution

- Uranium/chromium solution

- Aqueous mercury and lead

- Calcium Metal

- Waste sites/spill site soil

- Tank 3-1 clean out material

- Spent filter cartridges

- Mercury contaminated heavy water

- Nickel plating line solution

- Plating line sump material

- Safety/control rods

- Mark 15 filter paper

- M-Area sludge treatability samples

- M-Area high nickel plating line sludge

- Enriched uranium contaminated with lead

- M-Area plating line sludge from supernate treatment

- Silver-coated packing material

- Tri-butyl phosphate \& N-paraffin

- Job waste containing solvent contaminated wipes

- Job waste with enriched uranium and solvent applicators

- Mark 15 filtercake

- Tetrabutyl titanate 
Assumptions used in developing the future generation are as follows:

- Volumes of mixed waste for the outyears (1998-2024) were taken from questionnaires obtained from each waste generator onsite. The annual waste generation was changed according to responses received on the questionnaire. Specifically, each generator developed an average annual generation and identified changes to that average for future years.

- Where generators provided a total quantity of mixed waste generated and did not provide a percentage breakdown of the total into individual waste streams, the percentage breakdown provided in 1997 was used to break down the outyear totals into waste streams.

Based on the assumptions and the data contained in the Phase I report (Reference 4), a breakdown of the MW forecast by waste stream was obtained (Appendix A, Table A.2). These numbers were summed according to treatability groups to obtain a forecast by treatability group (Table 2).

\section{Hazardous Waste}

The HW treatability groups identified for the EIS are similar to those in the Mixed Waste Inventory Report. These treatability groups are consistent with the DOE guidance on mixed waste treatability groups. This grouping was based on similar chemical and physical characteristics.

The hazardous waste annual generation, as shown on the attached tables, was compiled following the method described below. The current inventory was obtained from the Hazardous Waste Building Inventory Database, combining the volumes for each hazardous waste index to obtain generation rates for the treatability groups identified in the attached table. These volumes are current as of May $1,1994$.

The future generation volumes were obtained from the Thirty-Year Solid Waste Generation Forecast for Facilities at SRS (Reference 4). These volumes best represent the waste volumes and the breakdown of future hazardous waste generation at SRS. For the 1995-1997 period, waste generators gave descriptions of the waste types and annual volumes anticipated to be generated. The descriptions and generation rates provided in the forecast were used to place the volumes into the already identified treatability groups.

The following treatability groups for hazardous waste were established based on the physical characteristics of the waste. These groups include waste with similar physi- cal and chemical characteristics. Under each treatability group is a listing of the applicable hazardous waste streams.

Polychlorinated Biphenyls

- Nonradioactive PCBs

Heterogeneous Debris

- Miscellaneous TC wastes-solid

- Batteries

\section{Aqueous/Organic Liquids}

- Miscellaneous TC wastes-liquid

- Ignitable and miscellaneous TC

- Miscellaneous solvents

- Spent varnish and paint

\section{Inorganic Debris}

- Low mercury waste (glass)

Soil

- Contaminated soil

Lead

- Lead smelter and soil waste

\section{Organic Debris}

- Halogenated solvents (toxic cleanup material)

An additional treatability group identified in the tables as "Current" in the column headings is comprised of the total volume of the wastes that have a current inventory onsite but are not anticipated to have future generation. These wastes have been identified to accurately represent the current inventory of wastes onsite; however, their individual characteristics and volumes are not identified here. The following is a list of those hazardous waste indices that are included in this group:

- Miscellaneous excess lab chemicals

- Halogenated degreasing solvents

- Miscellaneous metals (excess raw materials)

- Reactive wastes

- Tear gas concentrate 
Assumptions used in developing the future generation are as follows:

- Volumes of hazardous waste for the outyears (19982024) were taken from questionnaires obtained from each waste generator onsite. The annual waste generation was changed according to responses received on the questionnaire. Specifically, each generator developed an average annual generation and identified changes to that average for future years.

- Where generators only provided a total quantity of hazardous waste generated and did not provide a percentage breakdown of the total into individual waste streams, the percentage breakdown provided in 1997 was used to breakdown the outyear totals into waste streams.

Based on the assumptions and the data contained in the Phase I report (Reference 4), a breakdown of the hazardous waste forecast by waste stream was obtained (Appen$\operatorname{dix}$ A, Table A.3). These numbers were summed according to treatability groups to obtain a forecast by treatability group (Table 3).

\section{TRU/TRU Mixed Waste}

The TRU/TRU mixed category was based on the transuranic contaminants. The treatment for TRU or TRU mixed wastes will be the same. The treatment options will be dependent on the level of radioactivity.

Activity levels and present storage methods for the following treatability groups were created for TRU waste, based on engineering judgment. Under each treatability group is a listing of the applicable TRU waste streams.

\section{Low Activity Waste Requiring No Processing}

- $<100 \mathrm{nCi} / \mathrm{gm}$ waste being managed as TRU

\section{Low Activity Waste Requiring Processing}

- $<100 \mathrm{nCi} / g m$ mixed waste being managed as TRU

- $>100 \mathrm{nCi} / \mathrm{gm} \&<0.5 \mathrm{Ci}$ TRU waste

- $>100 \mathrm{nCi} / \mathrm{gm} \&<0.5 \mathrm{Ci}$ TRU mixed waste

High Activity Waste Requiring Processing

- >0.5 Ci TRU waste

- >0.5 Ci TRU mixed waste

- Bulky equipment and miscellaneous items

- Mixed waste bulky equipment

- Remote-handled TRU waste

- Remote-handled mixed TRU waste
The present TRU waste current inventory, as of December 31, 1993, and future estimated generation were divided into the listed waste streams identified above and shown on the attached tables in Appendix A. It is based on a compilation of the best available information from References 1 through 4 , the computerized radioactive waste burial records analysis system, and technical discussions with the cognizant engineering manager for TRU.

The TRU waste forecasted generation as shown on the attached tables is based on a compilation of the best available information contained within Reference 4 . In addition to the assumptions outlined within Reference 4, the following assumptions and data manipulations were made:

- One 55-gallon drum, with a polyethylene liner $=7 \mathrm{ft}^{3}$ had an internal capacity $=0.1981 \mathrm{~m}^{3}$.

- There is no waste that is $\geq 0.5 \mathrm{Ci} /$ package that is $<100$ nCi/g.

- Values provided for 1995 through 1997 were averaged to obtain a yearly average generation rate in terms of TRU non-mixed (23\% of the TRU waste generated per year), TRU bulky (60\% of the TRU waste generated per year), and TRU mixed (17\% of the TRU waste generated per year).

- Based on percentages from the current inventory for drummed waste, the following was determined:

- Percentage of waste generated that is $<100 \mathrm{nCi} / \mathrm{gm}$ is equal to $41 \%$

- Percentage of waste generated that is $>100 \mathrm{nCi} / \mathrm{gm}$ and $<0.5 \mathrm{Ci} /$ package is equal to $29.5 \%$

- Percentage of waste generated that is $>0.5 \mathrm{Ci} / \mathrm{pack}$ age is equal to $29.5 \%$.

- Items listed as other or different from a 55-gallon drum were summed to obtain the bulky equipment inventories.

Based on the above assumptions, the data from Reference 4 was taken and the assumption above was applied to obtain a breakdown of the forecast by waste stream (Appendix A, Table A-4). These numbers were summed according to the treatability groups to obtain a forecast by treatability group (Table 4). 
Table 1. Low-level Waste Operations Generation Forecast by Treatability Group

\begin{tabular}{|c|c|c|c|c|c|c|}
\hline Year & Long Lived & Tritiated & Bulk & Soils & Job Control & Total \\
\hline & & & & & Waste & \\
\hline Current & 0 & 0 & 1190 & 0 & 0 & 1190 \\
\hline 1995 & 1 & 3 & 29 & 578 & 15255 & 15866 \\
\hline 1996 & 1 & 3 & 29 & 621 & 15883 & 16537 \\
\hline 1997 & 1 & 3 & 29 & 630 & 15911 & 16574 \\
\hline 1998 & 1 & 3 & 29 & 287 & 14932 & 15252 \\
\hline 1999 & 1 & 3 & 29 & 287 & 14728 & 15048 \\
\hline 2000 & 1 & 3 & 29 & 287 & 16019 & 16339 \\
\hline 2001 & 1 & 3. & 29 & 287 & 15805 & 16125 \\
\hline 2002 & 1 & 3 & 29 & 287 & 15490 & 15810 \\
\hline 2003 & 1 & 3 & 29 & 291 & 12956 & 13280 \\
\hline 2004 & 1. & 3 & 29 & 291 & 10431 & 10755 \\
\hline 2005 & 1 & 3 & 29 & 291 & 10493 & 10817 \\
\hline 2006 & 1 & 3 & 29 & 291 & 9183 & 9507 \\
\hline 2007 & 1 & 3 & 29 & 291 & 9183 & 9507 \\
\hline 2008 & 1 & 3 & 29 & 291 & 9183 & 9507 \\
\hline 2009 & 1 & 3 & 29 & 291 & 9183 & 9507 \\
\hline 2010 & 1 & 3 & 29 & 291 & 9183 & 9507 \\
\hline 2011 & 1 & 3 & 29 & 291 & 9183 & 9507 \\
\hline 2012 & 1 & 3 & 29 & 291 & 9183 & 9507 \\
\hline 2013 & 1 & 3 & 29 & 291 & 9183 & 9507 \\
\hline 2014 & 1 & 3 & 29 & 291 & 9163 & 9487 \\
\hline 2015 & 1 & 3 & 29 & 291 & 9163 & 9487 \\
\hline 2016 & 1 & 3 & 29 & 291 & 9163 & 9487 \\
\hline 2017 & 1 & 3 & 29 & 291 & 9163 & 9487 \\
\hline 2018 & 1 & 3 & 29 & 291 & 9163 & 9487 \\
\hline 2019 & 1 & 3 & 29 & 291 & 9163 & 9487 \\
\hline 2020 & 1 & 3 & 29 & 291 & 9163 & 9487 \\
\hline 2021 & 1 & 3 & 29 & 291 & 9163 & 9487 \\
\hline 2022 & 1 & 3 & 29 & 291 & 9163 & 9487 \\
\hline 2023 & 1 & 3 & 29 & 291 & 9163 & 9487 \\
\hline 2024 & 1 & 3 & 29 & 291 & 9163 & 9487 \\
\hline \multirow[t]{2}{*}{ Totals } & 30 & 90 & 2060 & 9666 & 332160 & 344006 \\
\hline & & & & & & $\ddot{z}$ \\
\hline
\end{tabular}

Volume in Cubic Meters 
Table 3. Hazardous Waste Operations Generation Forecast by Treatability Group

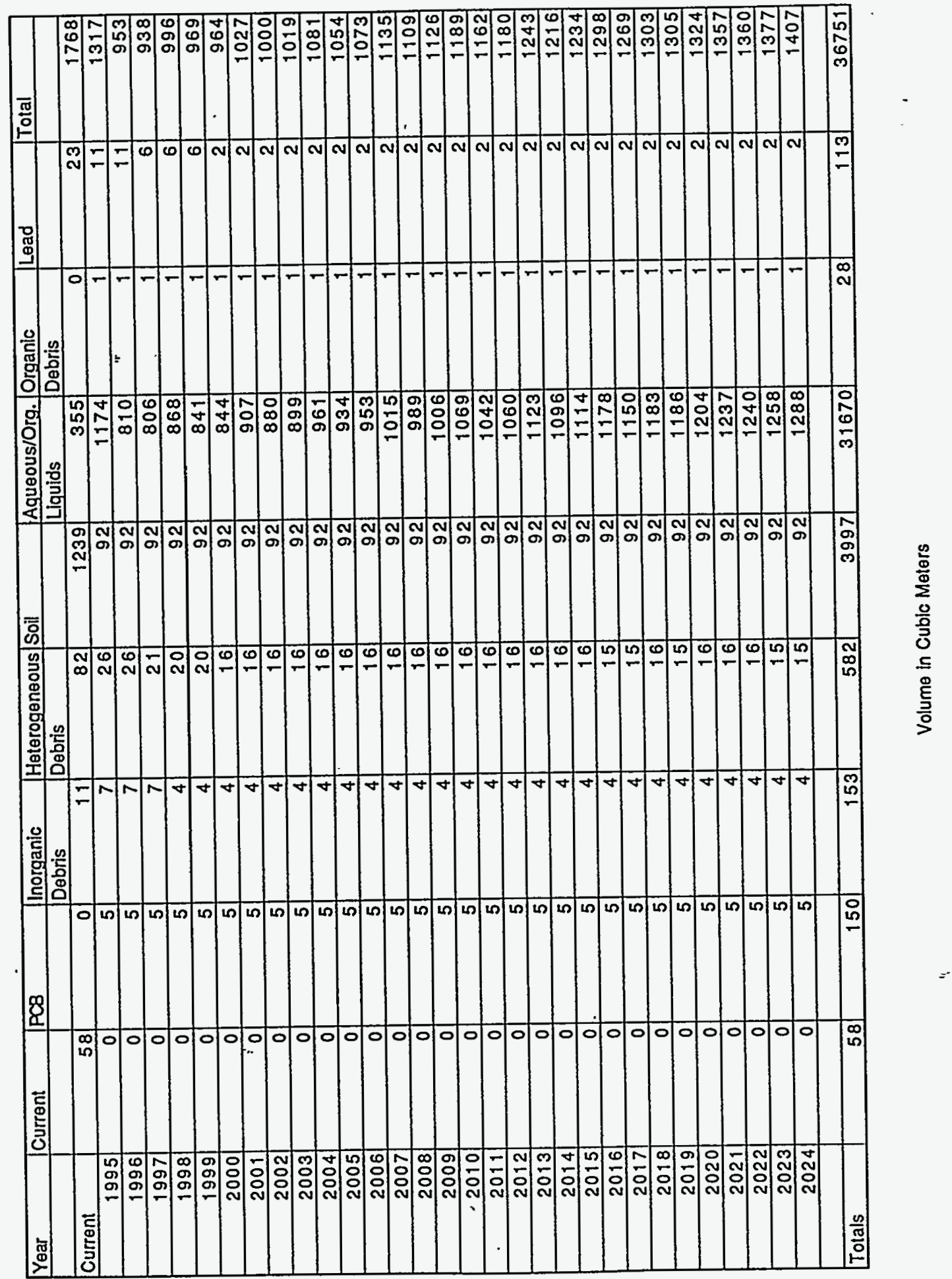


Table 4. Transuranic Waste Operations Generation Forecast by Treatability Group

\begin{tabular}{|c|c|c|c|c|}
\hline Year & Low Activity & High Activity & Low Activity & Total \\
\hline & W/Processing & & No Processing & \\
\hline Current & 4073 & 5910 & 70 & 10053 \\
\hline 1995 & 133 & 439 & 78 & 650 \\
\hline 1996 & 121 & 468 & 61 & 649 \\
\hline 1997 & 124 & 595 & 61 & 780 \\
\hline 1998 & 135 & 517 & 68 & 720 \\
\hline 1999 & 135 & 517 & 68 & 720 \\
\hline 2000 & 160 & 610 & 80 & 850 \\
\hline 2001 & 175 & 668 & 88 & 931 \\
\hline 2002 & 175 & 668 & 88 & 931 \\
\hline 2003 & 109 & 419 & 55 & 583 \\
\hline 2004 & 27 & 102 & 13 & 142 \\
\hline 2005 & 27 & 102 & 13 & 142 \\
\hline 2006 & 3 & 11 & 1 & 15 \\
\hline 2007 & 3 & 11 & 1 & 15 \\
\hline 2008 & 3 & 11 & 1 & 15 \\
\hline 2009 & 3 & 11 & 1 & 15 \\
\hline 2010 & 3 & 11 & 1 & 15 \\
\hline 2011 & 3 & 11 & 1 & 15 \\
\hline 2012 & 3 & 11 & 1 & 15 \\
\hline 2013 & 3 & 11 & 1 & 15 \\
\hline 2014 & 3 & 10 & 1 & 14 \\
\hline 2015 & 3 & 10 & 1 & 14 \\
\hline 2016 & 3 & 10 & 1 & 14 \\
\hline 2017 & 3 & 10 & 1 & 14 \\
\hline 2018 & 3 & 10 & 1 & 14 \\
\hline 2019 & 3 & 10 & 1 & 14 \\
\hline 2020 & 3 & 10 & 1 & 14 \\
\hline 2021 & 3 & 10 & 1 & 14 \\
\hline 2022 & 3 & 10 & 1 & 14 \\
\hline 2023 & 3 & 10 & 1 & 14 \\
\hline 2024 & 3 & 10 & 1 & 14 \\
\hline tals & 5444 & 11212 & 760 & \\
\hline
\end{tabular}

Volume in Cubic Meters 


\section{Decontamination and Decommissioning 30-Year Forecast by Treatability Group}

\section{Assumptions}

The following assumptions are in addition to those listed in the Phase I Report (Reference 4).

\section{Average Total Waste Volume (D\&D Activities)}

The objective of this effort is to estimate the total volume of waste generated by the D\&D program at SRS, not to estimate the waste generated by the D\&D of a individual facility.

It is assumed that the average total waste volume generated during D\&D activities taking a facility to greenfield is $1433.67 \mathrm{~m}^{3}$, based on information extrapolated from estimates of the first 53 facilities to undergo D\&D in 19951999. This volume includes the quantity of sanitary waste generated as a result of the D\&D. Greenfield involves removal of the facility, the foundation, and contaminated soil under the foundation.

Facility-specific waste generation volumes could be estimated by using the square footage data reported in the SFIA database. However, there is no D\&D schedule for the remaining 605 facilities; and, therefore, no basis to allocate waste volumes to individual years.

\section{Decontamination and Decommissioning to Greenfield}

During D\&D to greenfield, about 2 feet of soil under the building foundation will be removed. Of the soil removed, $15 \%$ will be contaminated and will be transported to a treatment, storage, and disposal (TSD) facility for disposition. The remaining $85 \%$ will not be contaminated and can be used as backfill.

\section{Contamination Due to Decontamination and Decommissioning}

If greater than $15 \%$ of the soil removed as a result of D\&D is contaminated, remediation such as treatment, in situ, or capping will be conducted on location; and, therefore, the soil will not be removed to a TSD facility for disposition.

\section{Average Total Waste Volume (to Foundation)}

The average total waste volume generated from taking a building to its foundation is $716.84 \mathrm{~m}^{3}$. This volume includes the quantity of sanitary -waste generated as a result of the D\&D. The sanitary waste stream from D\&D activities is approximately $35 \%$ of the total waste generation. This total volume $\left(716.84 \mathrm{~m}^{3}\right)$ is estimated to be half of the waste generated during a D\&D to greenfield. In this scenario, the building is removed but the building foundation and soil are not removed.

\section{Average Total Waste Volume (Gutting)}

The average total waste volume generated from gutting a building is $179.21 \mathrm{~m}^{3}$. This volume includes the quantity of sanitary waste generated as a result of the D\&D. The sanitary waste stream from D\&D activities is approximately $35 \%$ of the total waste generation. This total volume $\left(179.21 \mathrm{~m}^{3}\right)$ is estimated to be $25 \%$ of the waste generated during a $D \& D$ to foundation. Gutting a facility includes removing all materials, equipment, ductwork, process tanks and equipment, and decontaminating the remaining structure. The building structure will remain for other uses as required.

\section{Average Total Waste Volume (Removal Activ-} ities)

The mixed waste generation volumes in this forecast include all mixed wastes targeted for management by the Solid Waste Management Department and waste generated by routine Environmental Restoration activities. This volumes differs from the data in MWIR because MWIR does not currently include waste generated from routine Environmental Restoration activities.

\section{Data Manipulation}

\section{Waste Volume Generation Forecasts}

Waste volume generation forecasts for each waste category were divided into treatability groups on a fixed percentage basis. Distributing waste into treatability groups by percentages was based upon engineering assessment.

\section{Low-Level Waste (Taken to Foundation)}

The low-level waste category is divided into the following waste stream percentages when a facility is taken to its foundation: $3 \%$ long-lived, $5 \%$ tritiated, $10 \%$ bulk, $20 \%$ soils, $55 \%$ low activity job control waste, and $7 \%$ intermediate job control waste. 


\section{Mixed Waste (Taken to Foundation)}

The mixed waste category is divided into the following waste stream percentages when a facility is taken to its foundation: $10 \%$ metal debris, $15 \%$ soils, $15 \%$ inorganic debris, $25 \%$ heterogeneous debris, $2 \%$ aqueous liquids, $2 \%$ organic liquids, $2 \%$ glass debris, $10 \%$ bulk, $3 \%$ inorganic sludge, $5 \%$ lead, $3 \%$ organic sludge, $2 \%$ composite filters, $1 \%$ paint chips and solids, and $5 \%$ sand, gravel, and rock.

\section{Hazardous Waste (Taken to Foundation)}

The hazardous waste category is divided into the following waste stream percentages when a facility is taken to its foundation: $10 \%$ metal debris, $15 \%$ inorganic debris, $2 \%$ glass debris, $25 \%$ heterogeneous debris, $15 \%$ soils, $5 \%$ sand, gravel, and rock, $2 \%$ aqueous liquids, $2 \%$ organic liquids, $10 \%$ bulk, $5 \%$ lead, $3 \%$ inorganic sludge, $3 \%$ organic sludge, $2 \%$ composite filters, and $1 \%$ paint chips and solids.

\section{Transuranic Waste (Taken to Foundation)}

The TRU waste category is divided into the following waste stream percentages when a facility is taken to its foundation: $15 \%$ low activity, $75 \%$ high activity, and $10 \%$ no processing.

\section{Low-Level Waste (Gutted)}

The low-level waste category is divided into the following waste stream percentages when a facility is gutted: $1 \%$ long-lived, $4 \%$ tritiated, $25 \%$ bulk, $0 \%$ soils, $60 \%$ low activity job control waste, and $10 \%$ intermediate job control waste.

\section{Mixed Waste (Gutted)}

The mixed waste category is divided into the following waste stream percentages when a facility is gutted: $20 \%$ metal debris, $0 \%$ soils, $15 \%$ inorganic debris, $25 \%$ heterogeneous debris, $2.5 \%$ aqueous liquids, $2.5 \%$ organic liquids, $5 \%$ glass debris, $10 \%$ bulk, $2.5 \%$ inorganic sludge, $5 \%$ lead, $2.5 \%$ organic sludge, $3 \%$ composite filters, $5 \%$ paint chips and solids, and $2 \%$ sand, gravel, and rock.

\section{Hazardous Waste (Gutted)}

The hazardous waste category is divided into the following waste stream percentages when a facility is gutted: $20 \%$ metal debris, $15 \%$ inorganic debris, $5 \%$ glass debris, $25 \%$ heterogeneous debris, $0 \%$ soils, $2 \%$ sand, gravel, and rock, $2.5 \%$ aqueous liquids, $2.5 \%$ organic liquids, $10 \%$ bulk, $5 \%$ lead, $2.5 \%$ inorganic sludge, $2.5 \%$ organic sludge, 3\% composite filters, and 5\% paint chips and solids.

\section{Transuranic Waste (Gutted)}

The TRU waste category is divided into the following waste stream percentages when a facility is gutted: $15 \%$ low activity, $75 \%$ high activity, and $10 \%$ no processing.

\section{Waste Volumes Combined (Taken to Founda- tion and Gutted)}

The volume generated for each waste category was divided into the waste stream percentages for facilities taken to their foundation and were added to the volume generated for each waste category divided into the waste percentages for facilities to be gutted for each year. For example in the year 2000 , the volume of mixed waste metal debris generated is calculated as follows: $349.46 \mathrm{~m}^{3}$ (volume of mixed waste generated from gutting seven facilities) $\times 0.20+3404.99 \mathrm{~m}^{3}$ (volume of mixed waste generated from taking 17 facilities to foundation) $\times 0.10=$ $410.39 \mathrm{~m}^{3}$ of mixed waste metal debris generated from $D \& D$ in the year 2000 .

\section{Decontamination and Decommission- ing 30-Year Summary Tables}

See Tables 5 through 8 for a summary of D\&D waste generation by treatability group for each waste category over the next 30 years. 
Table 5. Low-level Waste D\&D Forecast by Treatability Group

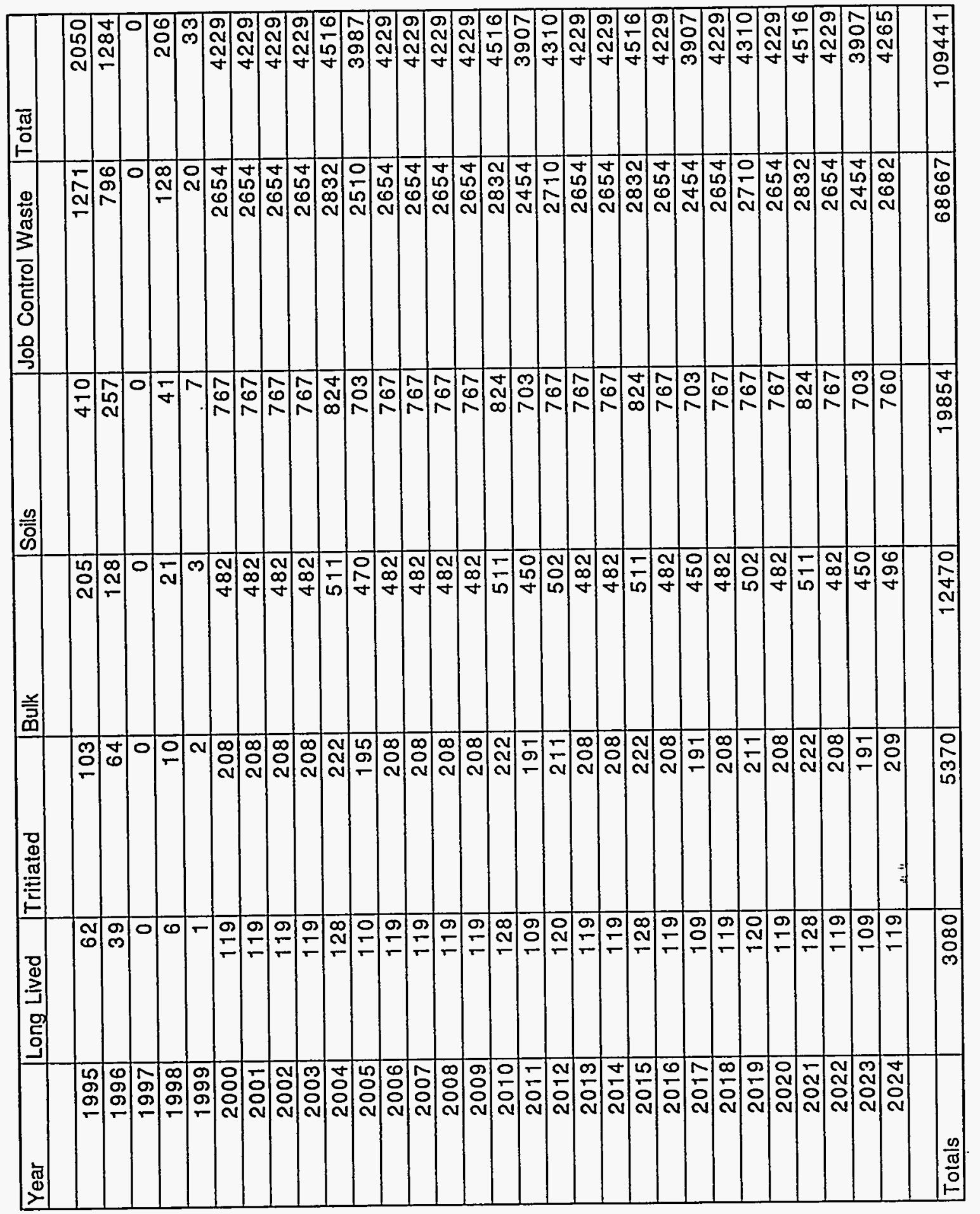




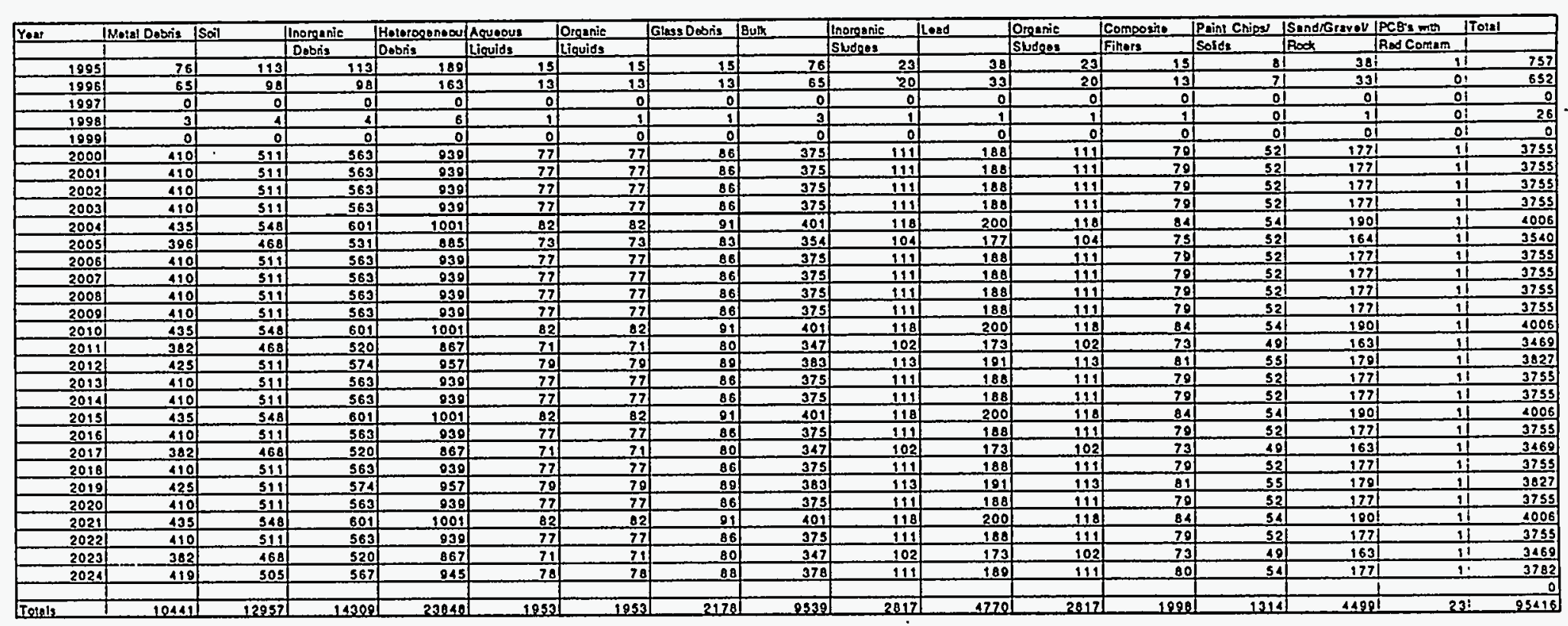




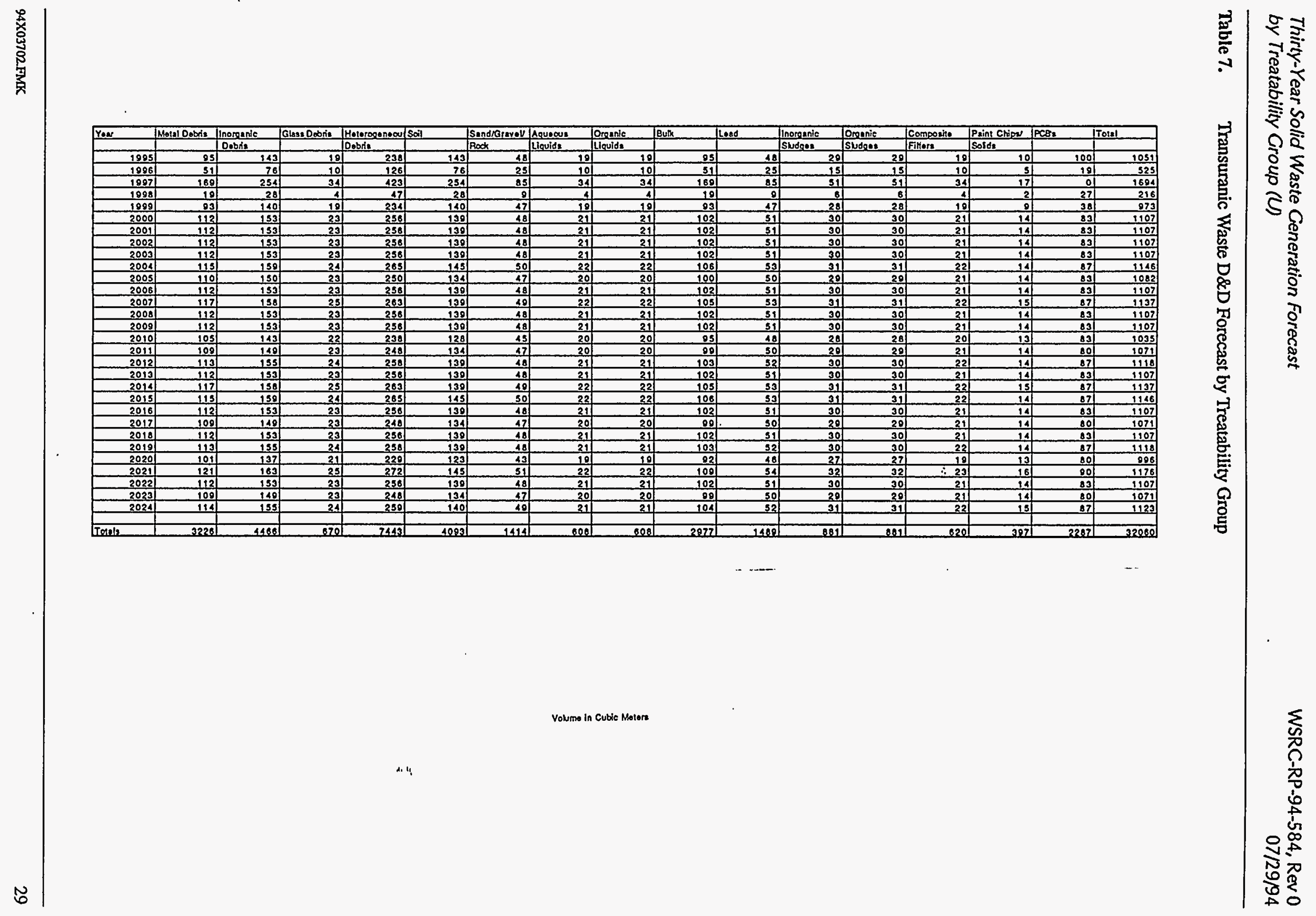


Table 8. Low-level Waste Environmental Restoration Forecast by Treatability Group

\begin{tabular}{|c|c|c|c|c|}
\hline Year & Low Activity & High Activity & Low Activity & Total \\
\hline & W/Processing & & No Processing & \\
\hline 1995 & 0 & 0 & 0 & 0 \\
\hline 1996 & 83 & 414 & 55 & 552 \\
\hline 1997 & 0 & 0 & 0 & 0 \\
\hline 1998 & 6 & 28 & 4 & 37 \\
\hline 1999 & 0 & 0 & 0 & 0 \\
\hline 2000 & 20 & 99 & 13 & 133 \\
\hline 2001 & 20 & 99 & 13 & 133 \\
\hline 2002 & 20 & 99 & 13 & 133 \\
\hline 2003 & 20 & 99 & 13 & 133 \\
\hline 2004 & 31 & 153 & 20 & 204 \\
\hline 2005 & 19 & 97 & 13 & 130 \\
\hline 2006 & 20 & 99 & 13 & 133 \\
\hline 2007 & 20 & 99 & 13 & 133 \\
\hline 2008 & 20 & 99 & 13 & 133 \\
\hline 2009 & 20 & 99 & 13 & 133 \\
\hline 2010 & 31 & 153 & 20 & 204 \\
\hline 2011 & 19 & 97 & 13 & 129 \\
\hline 2012 & 20 & 100 & 13 & 134 \\
\hline 2013 & 20 & 99 & 13 & 133 \\
\hline 2014 & 20 & 99 & 13 & 133 \\
\hline 2015 & 31 & 153 & 20 & 204 \\
\hline 2016 & 20 & 99 & 13 & 133 \\
\hline 2017 & 19 & 97 & 13 & 129 \\
\hline 2018 & 20 & 99 & 13 & 133 \\
\hline 2019 & 20 & 100 & 13 & 134 \\
\hline 2020 & 20 & 99 & 13 & 133 \\
\hline 2021 & 31 & 153 & 20 & 204 \\
\hline 2022 & 20 & 99 & 13 & 133 \\
\hline 2023 & 19 & 97 & 13 & 129 \\
\hline 2024 & 33 & 164 & 22 & 219 \\
\hline Totals & 640 & 3200 & 427 & 4266 \\
\hline
\end{tabular}

Volume in Cubic Meters 


\section{Environmental Restoration 30-Year Forecast by Treatability Group}

\section{Assumptions}

The following assumptions are in addition to those listed in the Phase I Report (Reference 4).

- All facilities identified in Appendices $\mathrm{C}$ and $\mathrm{H}$ of the FFA will undergo remediation to the ARAR levels agreed upon between DOE and the appropriate regulatory agency. Some waste generated through ER remediation will be removed from the cleanup site, while other waste generated during remediation will be treated, stabilized, and disposed at the site.

- The facilities identified in Appendices $\mathrm{C}$ and $\mathrm{H}$ of the FFA, and located within SRTC, 300 Area, 400 Area, TNX, and Reactor Areas (93 facilities), will generate waste that will need to be removed from the cleanup site. Of the facilities identified in Appendices $\mathrm{C}$ and $\mathrm{H}$, and located within E Area, F Area, and H Area (20\% of 36 or 7 facilities), $20 \%$ will generate waste that will need to be removed from the cleanup site. The remaining facilities located within $E, F$, and H Areas (29 facilities) may undergo some form of in situ remediation and be isolated. Accordingly, waste generated from the cleanup of these facilities will not be removed from the site.

- Of the facilities located within SRTC, 300 Area, 400 Area, TNX, and Reactor Areas and identified in Appendix $G$ (30\% of 143 or 43 facilities), $30 \%$ will generate waste that will need to be removed from the site.

- Of the spills identified in Appendix G, 50\% (or 67 spills) will generate waste that will need to be removed from the site.

- For spills, about $10 \mathrm{~m}^{3}$ of waste would be generated by the cleanup.

- For the Burial Ground Complex and Mixed Waste Management Facility, the waste generated will be treated in place and/or the facility will be capped.

\section{Data Manipulation}

- Estimates of the amount of waste generated for each waste category were divided into treatability groups on a fixed percentage basis. The basis for the percentage waste distribution into treatability groups was based upon engineering assessment.

- The low-level waste category is divided into the following waste stream percentages when a site or spill is remediated: $1 \%$ long-lived, $5 \%$ tritiated, $0 \%$ bulk, $90 \%$ soils, $3 \%$ low activity job control, waste, and $1 \%$ intermediate job control waste.

- The mixed waste category is divided into the following waste stream percentages when a site or spill is remediated: $3 \%$ metal debris, $75 \%$ soils, $1 \%$ inorganic debris, $2 \%$ heterogeneous debris, $1 \%$ aqueous liquids, $1 \%$ organic liquids, $1 \%$ glass debris, $1 \%$ bulk, $1 \%$ inorganic sludge, $1 \%$ lead, $1 \%$ organic sludge, $1 \%$ composite filters, $1 \%$ paint chips and solids, and $10 \%$ sand, gravel, and rock.

- The hazardous waste category is divided into the following waste stream percentages when a site or spill is remediated: $3 \%$ metal debris, $1 \%$ inorganic debris, $2 \%$ glass debris, $1 \%$ heterogeneous debris, $75 \%$ soils, $10 \%$ sand, gravel, and rock, $1 \%$ aqueous liquids, $1 \%$ organic liquids, $1 \%$ bulk, $1 \%$ lead, $1 \%$ inorganic sludge, $1 \%$ organic sludge, $1 \%$ composite filters, and $1 \%$ paint chips and solids.

- The TRU waste category is divided into the following waste stream percentages when a site or spill is remediated: $15 \%$ low activity, $75 \%$ high activity, and $10 \%$ no processing.

- For each year, the volume estimated for each waste category was divided into the waste stream percentages for site and spills remediated. For example in the year 2000 , the volume of mixed waste metal debris generated is estimated as follows: $1230 \mathrm{~m}^{3}$ (volume of mixed waste generated from remediating nine sites or spills) $\times$ $0.03=36.90 \mathrm{~m}^{3}$ of mixed waste metal debris generated from ER activities in the year 2000.

\section{Environmental Restoration 30-Year Summary Tables}

See Tables 9 through 12 for a summary of ER waste generation by treatability group for each waste category over the next 30 years. 
Table 9. Mixed Waste Environmental Restoration Forecast by Treatability Group

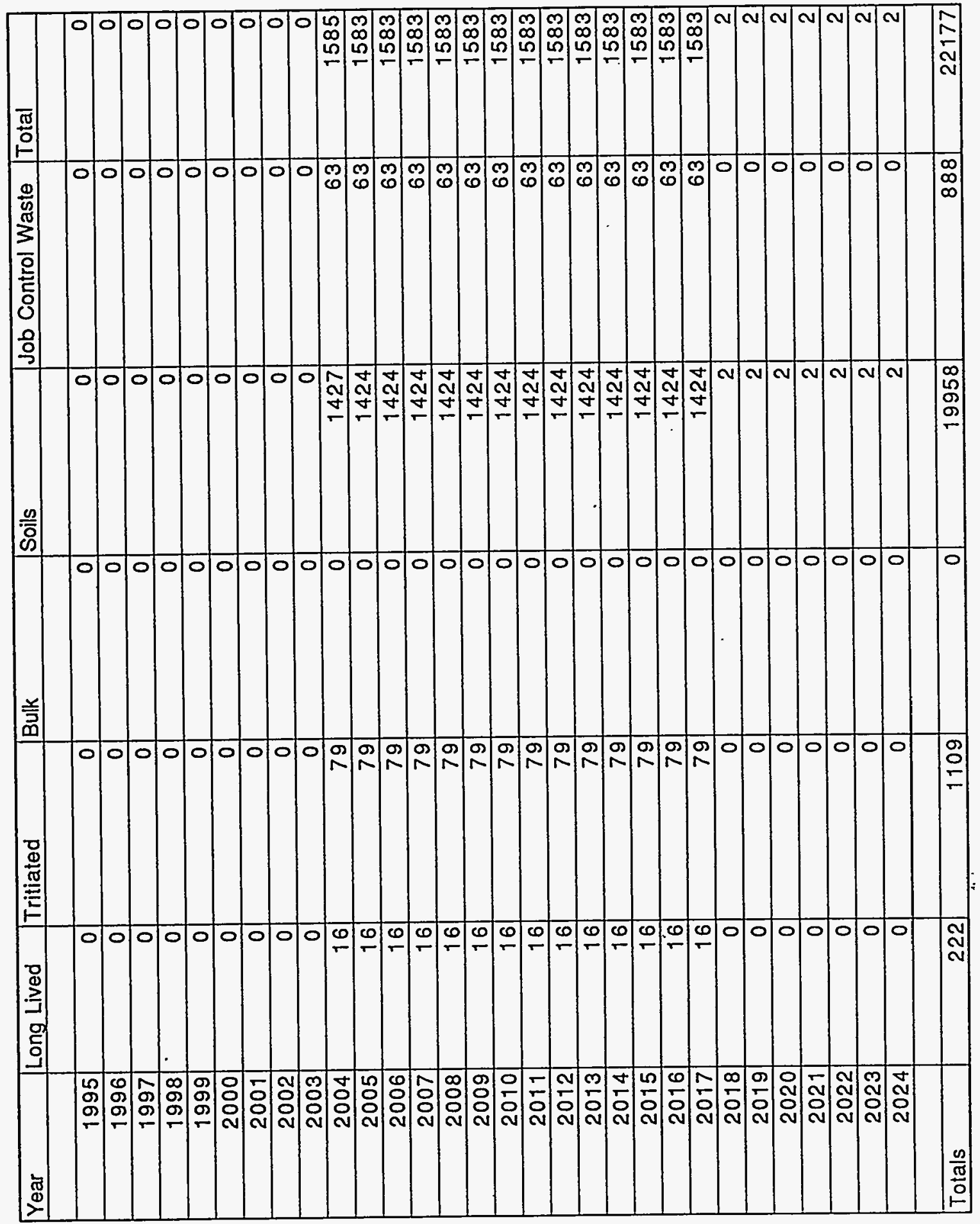




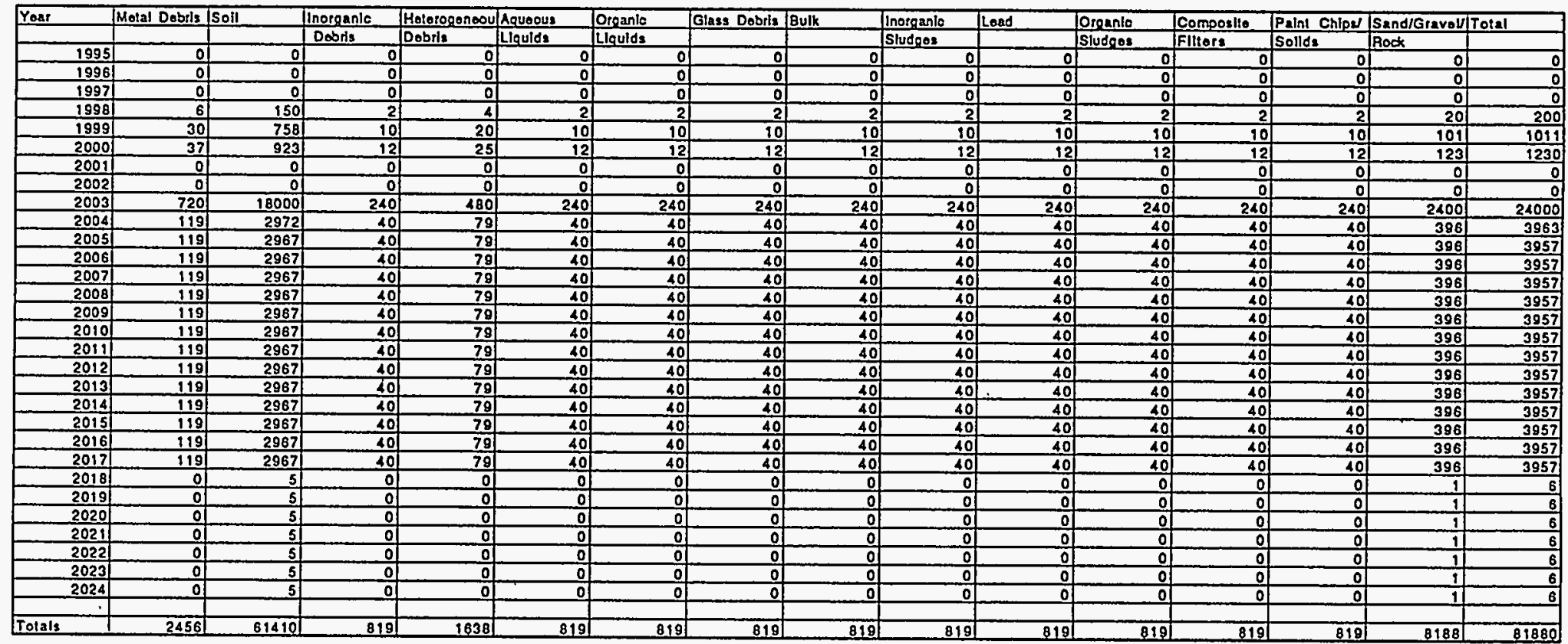




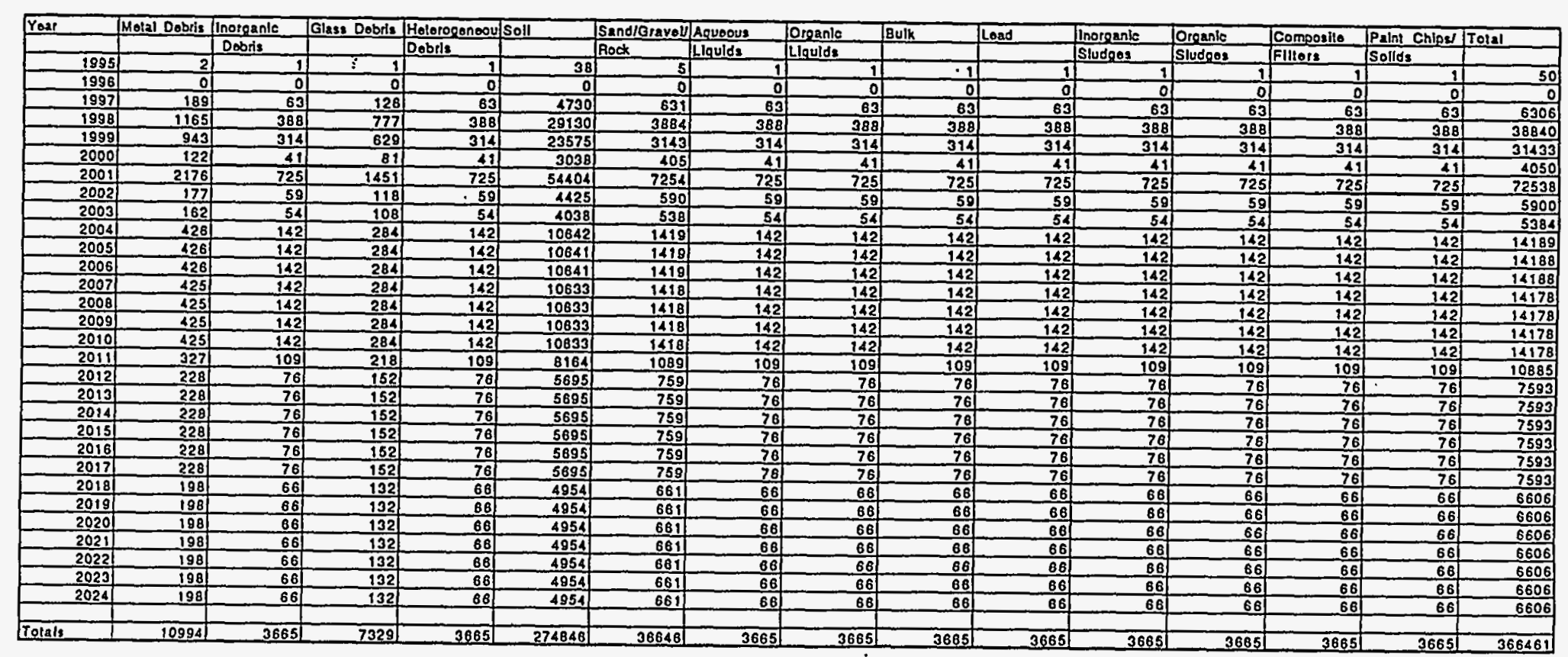


Table 12. Low-level Waste Summary Forecast by Treatability Group

\begin{tabular}{|c|c|c|c|c|}
\hline Year & Low Activity & High Activity & Low Activity & Total \\
\hline & W/Processing & & No Processing & \\
\hline 1995 & 0 & 0 & 0 & 0 \\
\hline 1996 & 0 & 0 & 0 & 0 \\
\hline 1997 & 0 & 0 & 0 & 0 \\
\hline 1998 & 0 & 0 & 0 & 0 \\
\hline 1999 & 0 & 0 & 0 & 0 \\
\hline 2000 & 0 & 0 & 0 & 0 \\
\hline 2001 & 0 & 0 & 0 & 0 \\
\hline 2002 & 0 & 0 & 0 & 0 \\
\hline 2003 & 0 & 0) & 0 & 0 \\
\hline 2004 & 10 & 50 & 7 & 66 \\
\hline 2005 & 10 & 49 & 7 & 66 \\
\hline 2006 & 10 & 49 & 7 & 66 \\
\hline 2007 & 10 & 49 & 7 & 66 \\
\hline 2008 & 10 & 49 & 7 & 66 \\
\hline 2009 & 10 & 49 & 7 & 66 \\
\hline 2010 & 10 & 49 & 7 & 66 \\
\hline 2011 & 10 & 49 & 7 & 66 \\
\hline 2012 & 10 & 49 & 7 & 66 \\
\hline 2013 & 10 & 49 & 7 & 66 \\
\hline . 2014 & 10 & 49 & 7 & 66 \\
\hline 2015 & 10 & 49 & 7 & 66 \\
\hline 2016 & 10 & 49 & 7 & 66 \\
\hline 2017 & 10 & 49 & 7 & 66 \\
\hline 2018 & 0 & 0 & 0 & 0 \\
\hline 2019 & 0 & 0 & 0 & 0 \\
\hline 2020 & 0 & 0 & 0 & 0 \\
\hline 2021 & 0 & 0 & 0 & 0 \\
\hline 2022 & 0 & 0 & 0 & 0 \\
\hline 2023 & 0 & 0 & 0 & 0 \\
\hline 2024 & 0 & 0 & 0 & 0 \\
\hline & & & 4 & \\
\hline Totals & 139 & 693 & 92 & 924 \\
\hline
\end{tabular}

Volume in Cubic Meters 


\section{Operations, Decontamination and Decommissioning, and Envi- ronmental Restoration Summary Forecast By Treatability Group}

See Tables 13 through 16 for a summary of operations, $D \& D$, and ER waste generation by treatability group for each waste category over the next 30 years. 
Table 13. Mixed Waste Summary Forecast by Treatability Group

\begin{tabular}{|c|c|c|c|c|c|c|}
\hline Year & Long Lived & Tritiated & Bulk & Soils & Job Control Waste & Total \\
\hline Current & 0 & 0 & 1190 & 0 & 0 & 1190 \\
\hline 1995 & 63 & 106 & 234 & 988 & 16526 & $\overline{17916}$ \\
\hline 1996 & 40 & 67 & 157 & 878 & 16679 & 17821 \\
\hline 1997 & 1 & 3 & 29 & 630 & 15911 & 16574 \\
\hline 1998 & 7 & 13 & 50 & 328 & 15060 & 15458 \\
\hline 1999 & 2 & $\underline{5}$ & 32 & 294 & 14748 & 15081 \\
\hline 2000 & 120 & 211 & 511 & 1054 & 18673 & 20568 \\
\hline 2001 & 120 & 211 & 511 & 1054 & 18459 & 20354 \\
\hline 2002 & 120 & 211 & 511 & 1054 & 18144 & 20039 \\
\hline 2003 & 120 & 211 & 511 & 1058 & 15610 & 17509 \\
\hline 2004 & 144 & 304 & 540 & 2542 & 13326 & 16856 \\
\hline 2005 & 127 & 277 & 499 & 2418 & 13067 & 16387 \\
\hline 2006 & 136 & 290 & 511 & 2482 & 11900 & 15319 \\
\hline 2007 & 136 & 290 & 511 & 2482 & 11900 & 15319 \\
\hline 2008 & 136 & 290 & 511 & 2482 & 11900 & 15319 \\
\hline 2009 & 136 & 290 & 511 & 2482 & 11900 & 15319 \\
\hline 2010 & 144 & 304 & 540 & 2540 & 12078 & 15606 \\
\hline 2011 & 126 & 274 & 479 & 2418 & 11700 & 14996 \\
\hline 2012 & 137 & 293 & 531 & 2482 & 11957 & 15400 \\
\hline 2013 & 136 & 290 & 511 & 2482 & 11900 & 15319 \\
\hline 2014 & 136 & 290 & 511 & 2482 & 11880 & 15299 \\
\hline 2015 & 144 & 304 & 540 & 2540 & 12058 & 15586 \\
\hline 2016 & 136 & 290 & 511 & 2482 & 11880 & 15299 \\
\hline 2017 & 126 & 274 & 479 & 2418 & 11680 & 14976 \\
\hline 2018 & 120 & 211 & 511 & 1060 & 11817 & 13719 \\
\hline 2019 & 121 & 214 & 531 & 1060 & 11873 & 13799 \\
\hline 2020 & 120 & 211 & 511 & 1060 & 11817 & 13719 \\
\hline 2021 & 129 & 225 & 540 & 1118 & 11995 & 14005 \\
\hline 2022 & 120 & 211 & 511 & 1060 & 11817 & 13719 \\
\hline 2023 & 110 & 195 & 479 & 996 & 11617 & 13396 \\
\hline 2024 & 120 & 212 & 525 & 1053 & 11845 & 13755 \\
\hline & & & & & & \\
\hline lotals & 3332 & 6569 & 14530 & 49478 & .401 .715 & 475624 \\
\hline
\end{tabular}

Volume in Cubic Meters 


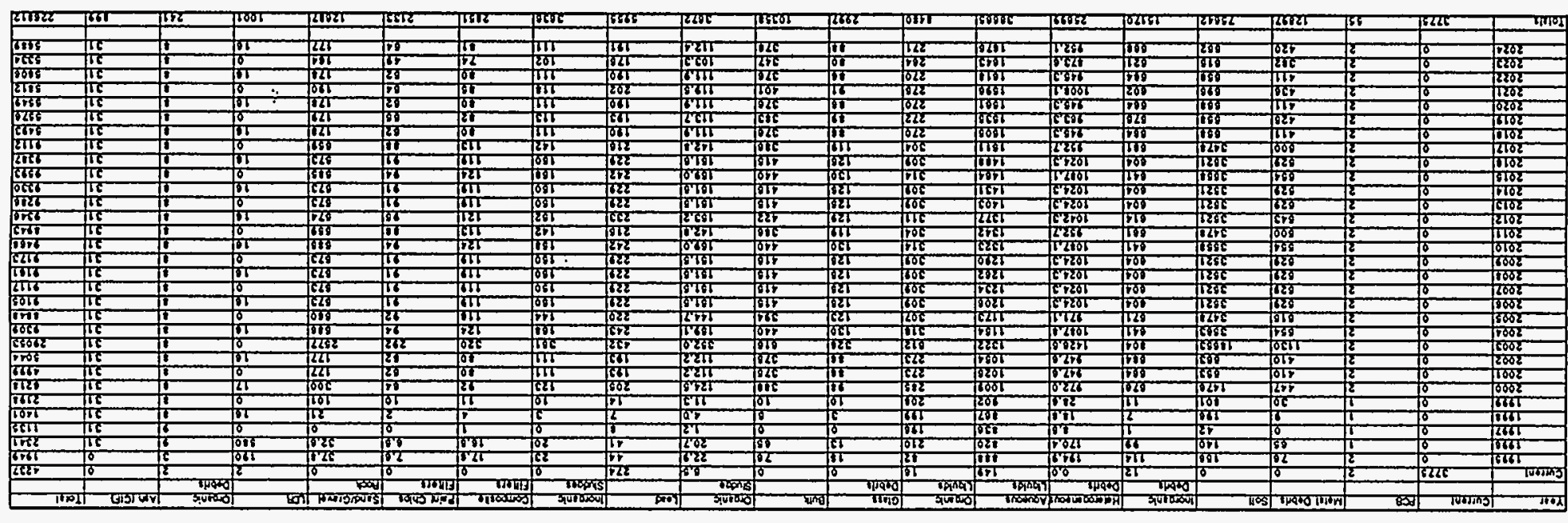


Table 15. Transuranic Waste Summary Forecast by Treatability Group

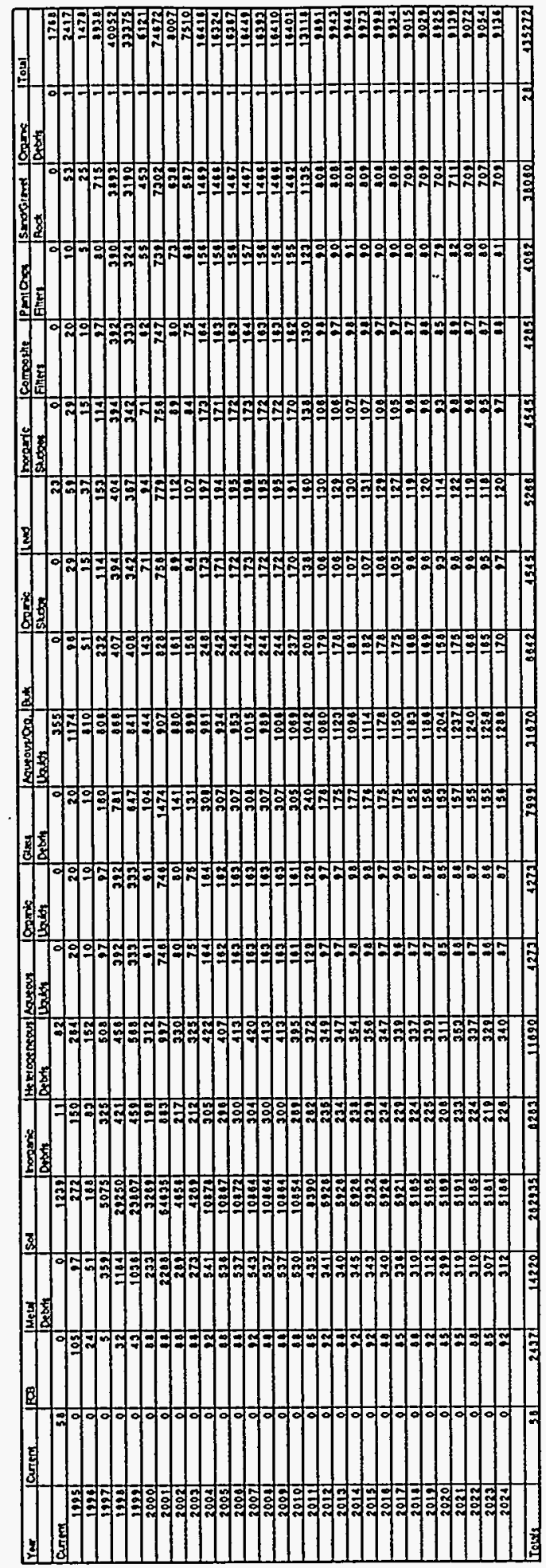


Table 16. Transuranic Waste Summary Forecast by Treatability Group

\begin{tabular}{|c|c|c|c|c|}
\hline Year & Low Activity & High Activity & Low Activity & Total \\
\hline & W/Processing & & No Processing & $\cdot$ \\
\hline Current & 4073 & 5910 & 70 & 10053 \\
\hline 1995 & 133 & 439 & 78 & 650 \\
\hline 1996 & 203 & 882 & 116 & 1201 \\
\hline 1997 & 124 & 595 & 61 & 780 \\
\hline 1998 & 141 & 545 & 72 & 757 \\
\hline 1999 & 135 & 517 & 68 & 720 \\
\hline 2000 & 179 & 710 & 93 & 983 \\
\hline 2001 & 195 & 768 & 101 & 1064 \\
\hline 2002 & 195 & 768 & 101 & 1064 \\
\hline 2003 & 129 & 518 & 68 & 716 \\
\hline 2004 & 67 & 305 & 40 & 412 \\
\hline 2005 & 56 & 249 & 33 & 338 \\
\hline 2006 & 33 & 160 & 21 & 214 \\
\hline 2007 & 33 & 160 & 21 & 214 \\
\hline 2008 & 33 & 160 & 21 & 214 \\
\hline 2009 & 33 & 160 & 21 & 214 \\
\hline 2010 & 43 & 213 & 28 & 285 \\
\hline 2011 & 32 & 157 & 21 & 210 \\
\hline 2012 & 33 & 160 & 21 & 214 \\
\hline 2013 & 33 & 160 & 21 & 214 \\
\hline 2014 & 32 & 159 & 21 & 213 \\
\hline 2015 & 43 & 213 & 28 & 284 \\
\hline 2016 & 32 & 159 & 21 & 213 \\
\hline 2017 & 32 & 156 & 21 & 209 \\
\hline 2018 & 23 & 110 & 15 & 147 \\
\hline 2019 & 23 & 110 & 15 & 148 \\
\hline 2020 & 23 & 110 & 15 & 147 \\
\hline 2021 & 33 & 163 & 22 & 218 \\
\hline 2022 & 23 & 110 & 15 & 147 \\
\hline 2023 & 22 & 107 & 14 & 143 \\
\hline 2024 & 35 & 174 & 23 & 233 \\
\hline Totals & 6222 & 15105 & 1288 & 22615 \\
\hline & & & & \\
\hline
\end{tabular}

Volume in Cubic Meters 


\section{References}

1. Savannah River Site FY 1994 Predecisional Draft Solid Waste Management Plan (U), Westinghouse Savannah River Company, WSRC-RP-93-1448, Revision 2.

2. SRS Mixed Waste Inventory Report (U), Westinghouse Savannah River Company, electronic database.

3. Savannah River Site Solid Waste Forecast-FY (94) $(U)$, Westinghouse Savannah River Company, Report, WSRC-RP-94-206, February 1994.

4. Thirty Year Solid Waste Generation Forecast for Facilities at SRS $(U)$, Westinghouse Savannah River Company, WSRC-RP-94-532, Revision 4, July 29 , 1994.

5. Thirty-Year D\&D Waste Generation Forecast for Facilities at SRS $(U)$, Westinghouse Savannah River Company, WSRC-RP-94-496, Revision 0, May 3, 1994.

6. Mission Need and Design Capacity Review (U), Westinghouse Savannah River Company, August 7, 1993.
7. Waste Acceptance Criteria (U), Westinghouse Savannah River Company, Procedure Manual WSRC 1S.

8. SRS Mixed Waste Inventory Report (U), Westinghouse Savannah River Company, electronic database.

9. WSRC Information Manual (U), Westinghouse Savannah River Company, Information Manual, WSRC-IM-93-10, Rev. 0, February 25, 1993.

10. South Carolina Hazardous Waste Management Regulations (SCHWMR) R.61-79.

11. "Debris Rule Promulgation", Federal Register (57 FR 37194), August 18, 1992.

12. Waste Minimization and Pollution Prevention Awareness Plan, Department of Energy, Savannah River Site, December 22, 1993.

13. Federal Facility Agreement Under Section 120 of CERCLA and Sections 3008(h) and 6001 of RCRA, Administrative Docket No: 89-05-FF, 1992. 
Appendix A 
Table A.1. Mixed Waste Operations Generation by Waste Stream

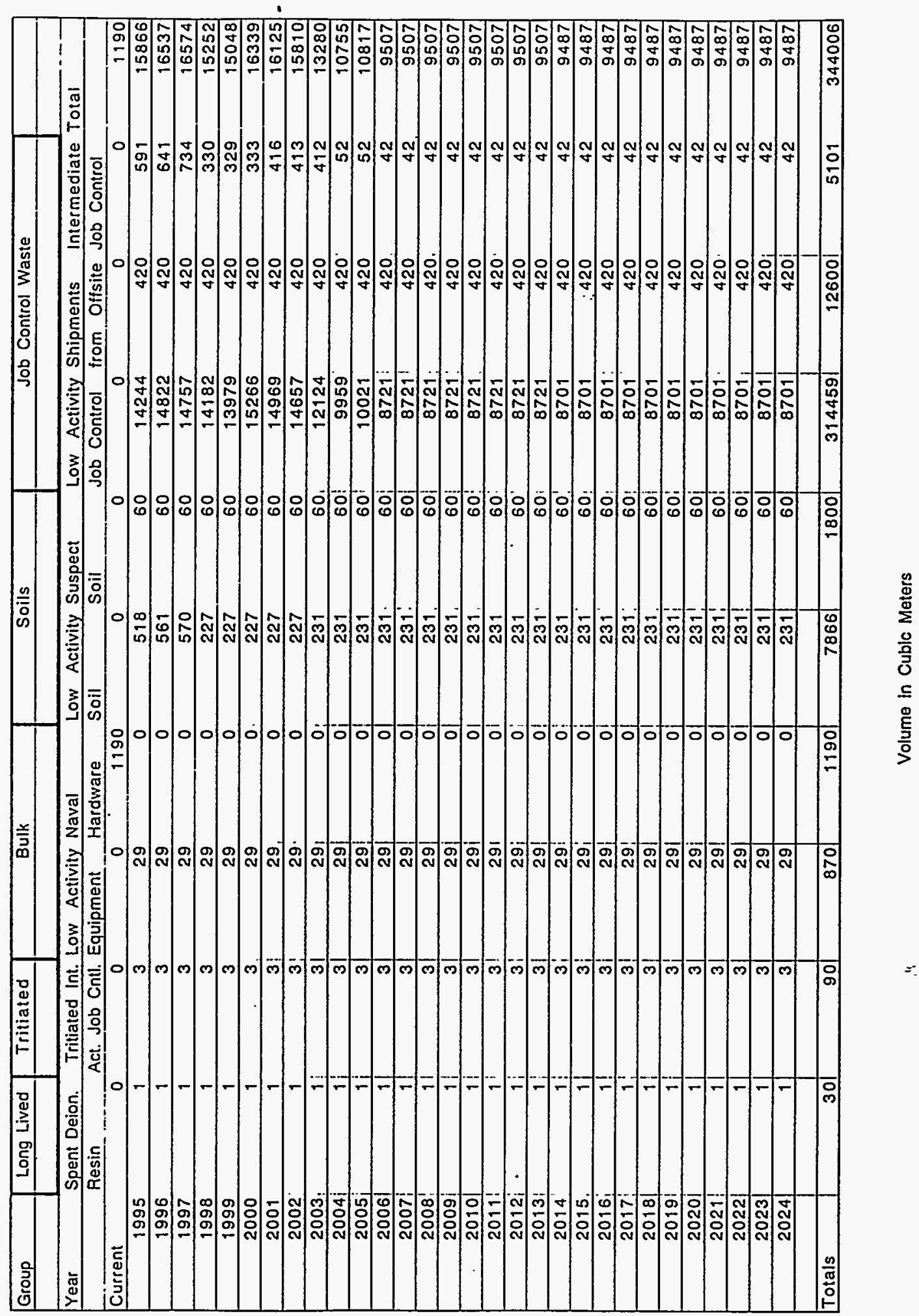




\section{Table A.2. Mixed Waste Operations Generation by Waste Stream}

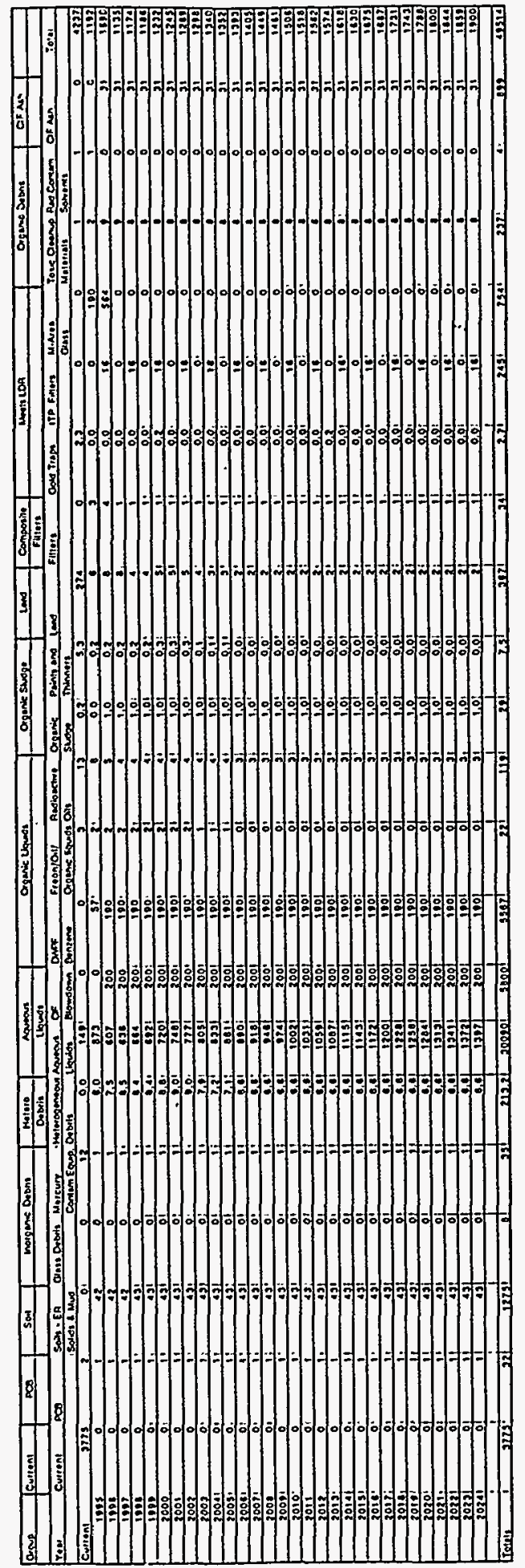

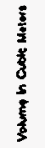




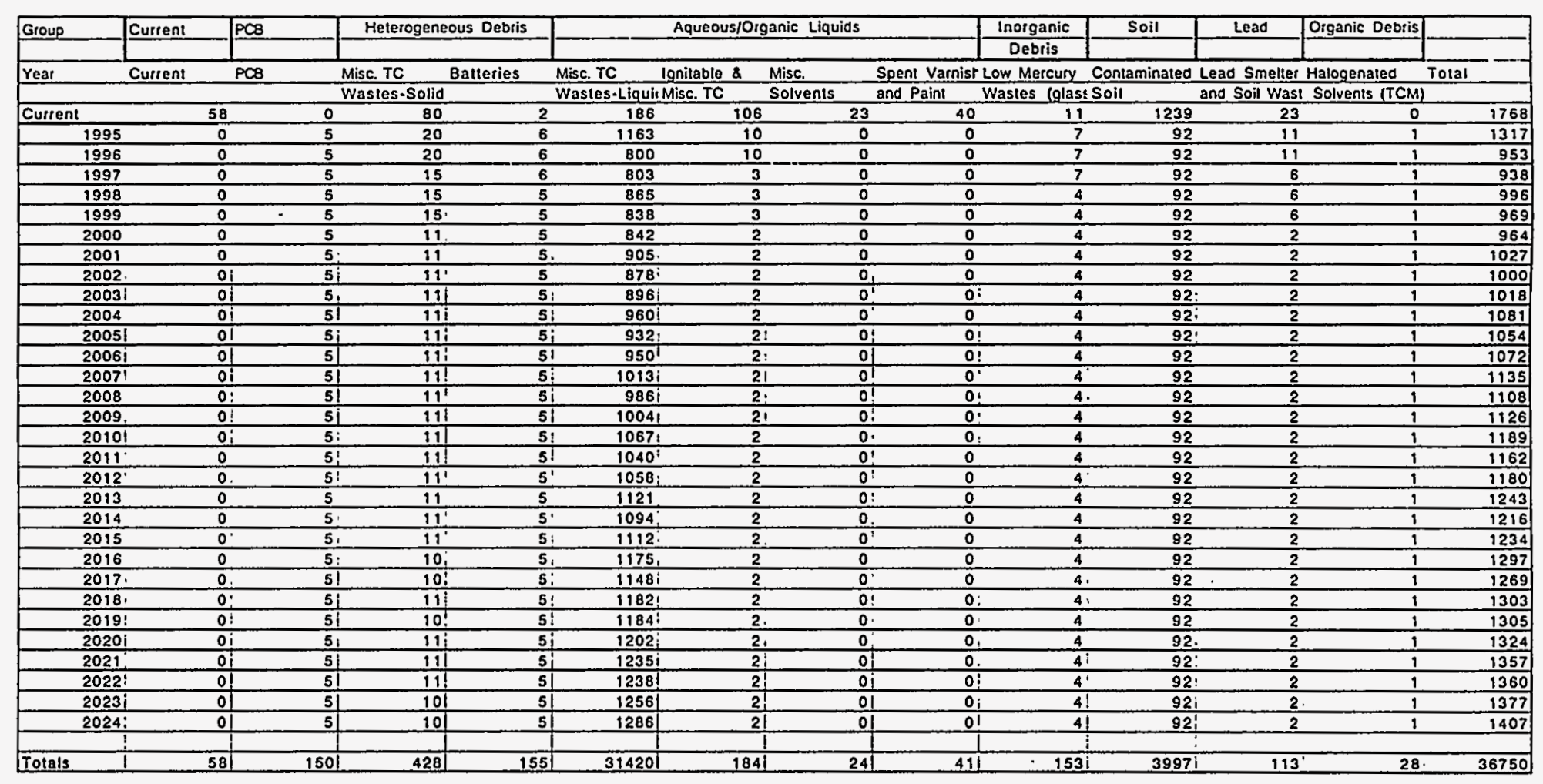




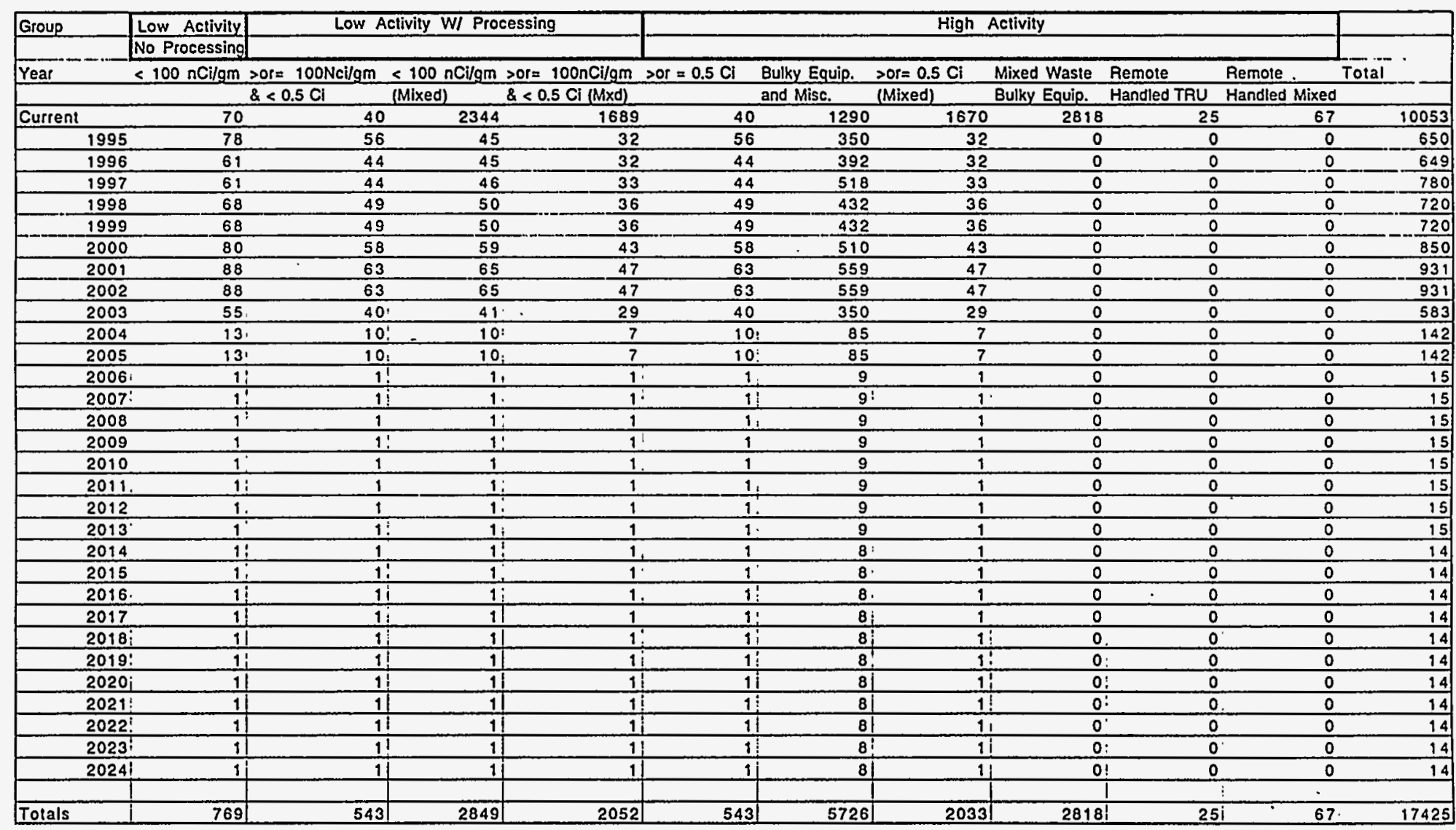

Volume in Cubic Meters 